\title{
Effects of Ni Concentration and Aging Heat Treatment on the Hydrogen Embrittlement Behavior of Precipitation-Hardened High- Mn Austenitic Steel
}

\author{
Takashi Hosoda ${ }^{1)^{*}}$, Yuhei Ogawa ${ }^{2,3)}$, Osamu Takakuwa ${ }^{2,3)}$, Susumu Motomura ${ }^{4)}$, Hyuga Hosoi $^{5)}$ \\ and Hisao MatsunaGa ${ }^{2,3,6)}$ \\ 1) Research \& Development Center, Sanyo Special Steel Co., Ltd. \\ 2) Department of Mechanical Engineering, Kyushu University \\ 3) Research Center for Hydrogen Industrial Use and Storage (HYDROGENIUS), Kyushu University \\ 4) Department of Hydrogen Energy Systems, Graduate School of Engineering, Kyushu University, now Takenaka \\ Corporation \\ 5) Department of Hydrogen Energy Systems, Graduate School of Engineering, Kyushu University, now Toyota \\ Motor Corporation \\ 6) International Institute for Carbon-Neutral Energy Research (I²CNER), Kyushu University
}

Abstract: The effects of Ni concentration and dispersed conditions of vanadium carbide (VC) nano-particles on the hydrogen embrittlement (HE) behavior of precipitation-hardened high-Mn austenitic steels were investigated under the presence of thermally pre-charged hydrogen. Slow strain-rate tensile tests revealed that HE susceptibility decreased with an addition of Ni. VC precipitates functioned as the trapping sites for dissolved hydrogen, though its effect on resisting the HE was trivial. Hydrogen enhanced intergranular (IG) fracture wherein its area fraction was increased with the hardening by $\mathrm{VC}$ as well as with the escalation of internal hydrogen concentration. The IG fracture was the primary rationale for the hydrogen-induced loss of ductility. Possible mechanisms of the IG-related HE as well as future strategy for mitigating the mechanical degradation is discussed based on the fractographic observation and post-mortem microstructural analyses.

Keywords: hydrogen embrittlement; high-Mn austenitic steel; precipitation-hardening; vanadium carbide.

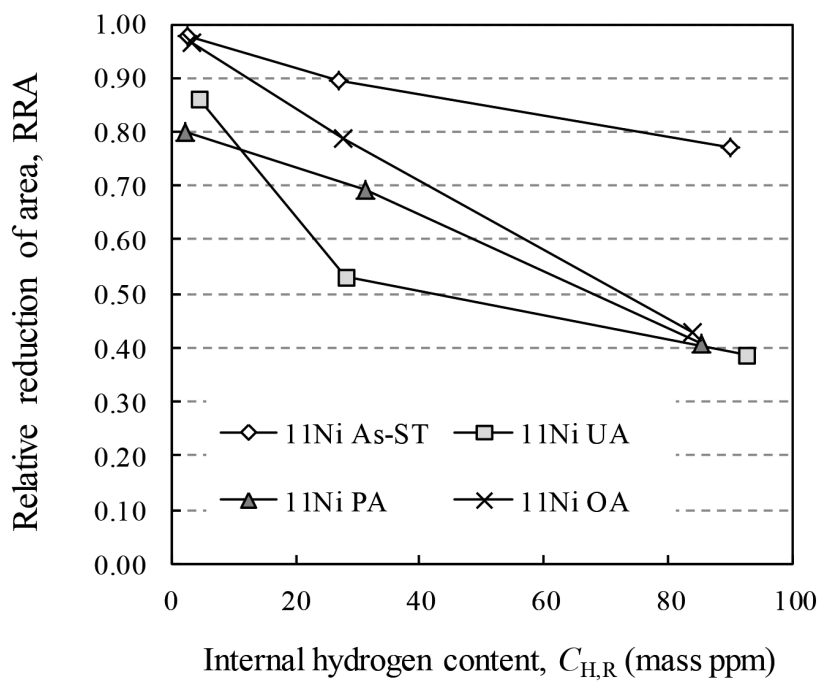

Received on Sep. 22, 2021; Accepted on Oct. 11, 2021; J-STAGE Advance published on Nov. 19, 2021

* Corresponding author. E-mail: thosoda@himeji.sanyo-steel.co.jp, Address: Sanyo Special Steel Co., Ltd., 3007 Nakashima Shikama-ku Himeji Hyogo 672-8064 


\title{
析出硬化型高 Mnオーステナイト鋼の水素脆化挙動に及ぼす $\mathrm{Ni}$ 含有量および時効熱処理の影響
}

\author{
細田 孝 ${ }^{1} *$ ·小川 祐平 ${ }^{2,3)} \cdot$ 高桑 脩 ${ }^{2,3)} \cdot$ 本村 達 ${ }^{4)} \cdot$ 細井 日向 ${ }^{5)} \cdot$ 松永 久生 $^{2,3,6)}$ \\ Effects of Ni Concentration and Aging Heat Treatment on the Hydrogen Embrittlement Behavior \\ of Precipitation-Hardened High-Mn Austenitic Steel \\ Takashi Hosoda, Yuhei Ogawa, Osamu Takakuwa, Susumu Motomura, Hyuga Hosor and Hisao Matsunaga
}

\section{1. 緒言}

グローバルな資源確保と環境保全の観点から，水素エネ ルギー利用社会の実現に向けた取り組みが活発となって いる。日本に扎いては, 燃料電池自動車の市場リリースが 2014年に実現され，その普及に対応していく形で水素ス テーションの増設も進められている ${ }^{1,2)}$ 。

鉄鋼材料は, 水素社会でもインフラ整備やアプリケー ション普及への貢献が期待される材料である。しかし，水 素環境下で使用する場合, 材料本来の機械的性能が低下す る水素脆化の発現 ${ }^{3,4)}$ が危惧されるため, 十分な耐水素性 を持つ鋼を選定していく必要がある。耐水素性の高い鋼と してよく知られているのは, オーステナイト (以下, $\gamma)$ 系 ステンレス鋼である。これは，フェライトやマルテンサイ 卜を基地組織とする鋼と比べ, $\gamma$ 組織の水素拡散係数が大 幅に小さいため，材料中への水素の侵入が困難であること に由来するとされている ${ }^{5,6)}$ 。鋼の代表的なものの 1 つに, JIS 規格に打ける $\gamma$ 系ステンレス鋼SUS316Lが挙げられる。 同材料は水素環境中での使用を模擬した各種試験を経て, 優れた耐水素性を有することが確認されており ${ }^{7,8)}$, 水素機 器の各種部材に利用されている。今後, 水素環境用部材に は更なる薄肉・軽量化が期待されるが, SUS316Lは強度が 低く, その要求に応えることが難しくなる。一方, 耐水素 性と高強度を両立したJIS 規格鋼に，SUH660（A286合金と 同等) がある。SUH660 は析出硬化熱処理にて $1000 \mathrm{MPa}$ 超える引張強さを示す $\gamma$ 鋼であり, 試験中に侵入する水素 (外部水素) による引張特性の低下はほとんど皆無である
ことが実証されてきた ${ }^{9,10)}$ 。ただし，SUH660はNi含有量が 約 25 mass \%と多く, 高価な鋼材である。また, 外部水素に 対して優れた耐水素性を示す反面, 陰極チャージや高圧水 素ガス曝露にて予め試験片内に水素をチャージし, 内部水 素を存在させた状態で引張試験を実施した場合には，有意

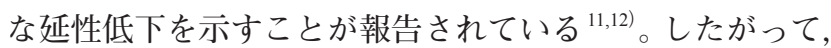
高圧水素環境中で高強度 $\gamma$ 鋼を安全に利用するためには, 外部水素のみならず, 内部水素が材料特性に及ぼす影響を 把握する必要がある。

高圧水素機器の低コスト化と高性能化には, SUH660と 同等以上の耐水素性と高強度を併せ持ち, かつ安価 (省合 金) な鋼材の供給が望まれる。このニーズに応え得る候補 材料として, 本研究では析出硬化型高 $\mathrm{Mn}-\gamma$ 鋼に着目した。 本鋼は安価な Mnの積極利用により $\mathrm{Ni}$ 含有量を抑えつつ $\gamma$ 組織を安定化させ, バナジウム炭化物 (VC) の微細分散を 強化因子に用いて約 $1200 \mathrm{MPa}$ の引張強さに達するように 設計されたものである。また, VCを含む析出物は侵入し た水素のトラップサイトとして作用し, 水素による材料特 性への悪影響を抑制する効果が認められている ${ }^{13-15)}$ ため, 鋼材の高強度化と耐水素性向上の双方に寄与する可能性 がある。以上の通り，析出硬化型高 Mn- $\gamma$ 鋼はSUH660より も強度レベルが高く, 今後の水素環境用部材のさらなる小 型・軽量化へと貢献していくことが期待されるが, 実際に 利用していくためには, その水素脆化感受性や, 脆化メ力 ニズムを明らかにしておく必要がある。

本研究では, 最も一般的な $\gamma$ 安定化元素である $\mathrm{Ni}$ の含有 量, ならびに時効熱処理によって VCの析出状態を変化さ

2021年9月22日受付２021年10月11日受理２021年11月19日J-STAGE早期公開（Received on Sep. 22, 2021; Accepted on Oct. 11, 2021; J-STAGE Advance published on Nov. 19, 2021)

1）山陽特殊製鋼 (株) 研究・開発センター (Research \& Development Center, Sanyo Special Steel Co., Ltd.)

2）九州大学大学院工学研究院機械工学部門 (Department of Mechanical Engineering, Kyushu University)

3）九州大学水素材料先端科学研究センター (HYDROGENIUS) (Research Center for Hydrogen Industrial Use and Storage (HYDROGENIUS), Kyushu University)

4）九州大学大学院水素エネルギーシステム専攻 (現: (株) 竹中工務店) (Department of Hydrogen Energy Systems, Graduate School of Engineering, Kyushu University, now Takenaka Corporation)

5）九州大学大学院水素エネルギーシステム専攻 (現:トヨタ自動車 (株)) (Department of Hydrogen Energy Systems, Graduate School of Engineering, Kyushu University, now Toyota Motor Corporation)

6）九州大学カーボンニュートラルエネルギー国際研究所 (I²CNER)（International Institute for Carbon-Neutral Energy Research (I2CNER), Kyushu University)

* Corresponding author. E-mail: thosoda@himeji.sanyo-steel.co.jp, Address: Sanyo Special Steel Co., Ltd., 3007 Nakashima Shikama-ku Himeji Hyogo $672-8064$ 
せた複数の析出硬化型高 $\mathrm{Mn}-\gamma$ 鋼に対して高温 - 高圧水素 ガス中での水素チャージを施した後に, 低ひずみ速度引張 試験を行った。水素侵入に伴う引張特性と破壊挙動の変化 の調査を通して, 本鋼種における $\mathrm{Ni}$ 含有量と時効熱処理に 伴う組織状態の変化が耐水素性に及ぼす影響と, 内部水素 による水素脆化メカニズムを検討した。

\section{2. 供試材および実験方法}

\section{$2 \cdot 1$ 供試材および試験片}

$\mathrm{Ni}$ 含有量の異なる2種類の $50 \mathrm{~kg}$ 鋼塊を真空誘導炉に て溶製した。それらの化学成分と, 各鋼塊の平均組成か ら Hirayama and Ogirima ${ }^{16)}$ の式を用いて算出した Ni等量： $\mathrm{Ni}_{\mathrm{eq}}$ を Table 1 に示す。 $\mathrm{Ni}_{\mathrm{eq}}$ は, 塑性変形中の $\gamma$ 安定度，すな わち加工誘起マルテンサイト変態の難度を表す指標とし て一般に用いられている。以後，Ni含有量に因んでそれぞ れの鋼種を $7 \mathrm{Ni}, 11 \mathrm{Ni}$ と呼称する。11Ni は7 $7 \mathrm{Ni} よ り も ~ \mathrm{Ni}_{\mathrm{eq}}$ が 高く, $\gamma$ 安定度がより高い鋼種である。これらを直径 $15 \mathrm{~mm}$ に熱間鍛造して棒材としたものを出発材とした。熱間鍛造 後, $1180^{\circ} \mathrm{C}-30 \mathrm{~min}$ 保持後水冷により溶体化処理したもの をAs-ST と呼称する。次いで, VC析出にて時效硬化させる とともに，その析出状態を変化させるため, $650^{\circ} \mathrm{C}, 750^{\circ} \mathrm{C}$, $800^{\circ} \mathrm{C}$ で各 $2 \mathrm{hr}$ 等温保持後空冷の時効処理を施した。以後, $650^{\circ} \mathrm{C}, 750^{\circ} \mathrm{C}, 800^{\circ} \mathrm{C}$ 時効後の材料をそれぞれUA, PA, OA と呼称する。

Table 2 に, 各供試材の熱処理履歴とロックウェル硬さ の測定結果を示す。硬さの測定位置は，断面内中周部（棒 材直径の $1 / 4$ に相当する位置) とした。いずれの供試材も， $750^{\circ} \mathrm{C}$ 時効で最大 (ピーク) 硬さを示す。 $650^{\circ} \mathrm{C}$ と $800^{\circ} \mathrm{C}$ 時効

Table 1. Chemical compositions and $\mathrm{Ni}_{\mathrm{eq}}$ of the two high-Mn steels (mass \%). $\mathrm{Ni}_{\mathrm{eq}}$, as an index of austenite phase stability, is shown together which was calculated via an equation derived in the literature: $\mathrm{Ni}_{\mathrm{eq}}=12.6[\mathrm{C}]+$ $0.35[\mathrm{Si}]+1.05[\mathrm{Mn}]+[\mathrm{Ni}]+0.65[\mathrm{Cr}]+0.98[\mathrm{Mo}]^{16)}$.

\begin{tabular}{c|c|c|c|c|c|c|c|c}
\hline Material & $\mathrm{C}$ & $\mathrm{Si}$ & $\mathrm{Mn}$ & $\mathrm{Ni}$ & $\mathrm{Cr}$ & $\mathrm{V}$ & $\mathrm{Fe}$ & ${ }^{*} \mathrm{Ni}_{\text {eq }}$ \\
\hline $7 \mathrm{Ni}$ & 0.45 & 0.24 & 8.5 & 7.1 & 10.1 & 1.5 & Bal. & 28.4 \\
\hline $11 \mathrm{Ni}$ & 0.46 & 0.26 & 8.5 & 11.1 & 10.1 & 1.5 & Bal. & 32.5 \\
\hline
\end{tabular}

Table 2. Heat treatment conditions, Rockwell hardness and acronym of the samples subjected to different heat treatments.

\begin{tabular}{c|l|c|c|c}
\hline \multirow{2}{*}{ Heat treatment } & \multicolumn{1}{|c|}{ Condition } & \multicolumn{2}{|c|}{ Rockwell hardness } & \multirow{2}{*}{ Acronym } \\
\cline { 3 - 4 } Solution treatment & $\begin{array}{l}1180^{\circ} \mathrm{C} \text { for } 30 \mathrm{~min}, \\
\text { water quenched }\end{array}$ & $91 \mathrm{HRB}$ & $91 \mathrm{HRB}$ & As-ST \\
\hline \multirow{4}{*}{ Aging } & $\begin{array}{l}650^{\circ} \mathrm{C} \text { for } 2 \mathrm{hr}, \\
\text { air cooled }\end{array}$ & $33 \mathrm{HRC}$ & $33 \mathrm{HRC}$ & $\mathrm{UA}$ \\
\cline { 2 - 4 } & $\begin{array}{l}750^{\circ} \mathrm{C} \text { for } 2 \mathrm{hr}, \\
\text { air cooled }\end{array}$ & $40 \mathrm{HRC}$ & $40 \mathrm{HRC}$ & PA \\
\cline { 2 - 4 } & $\begin{array}{l}800^{\circ} \mathrm{C} \text { for } 2 \mathrm{hr}, \\
\text { air cooled }\end{array}$ & $35 \mathrm{HRC}$ & $35 \mathrm{HRC}$ & OA \\
\hline
\end{tabular}

材の硬さはほぼ同等であるが，それぞれ亜時効，過時効状 態となるため, $\mathrm{VC}$ 粒子の析出状態は異なっていることに 注意されたい。熱処理履歴が同じ場合, 鋼種成分, つまり $\mathrm{Ni}$ 含有量の差は硬さに対して有意な影響を及ぼさなかっ た。

Fig.1（a）に, 引張試験片の形状と寸法を示す。試験片平 行部表面は, エメリー紙＃2000 およびバフによる軸方向研 磨にて鏡面に仕上げた。Fig.1 (b) に, 水素量測定用試験片 を示す。直径 $5 \mathrm{~mm}$, 高さ $3 \mathrm{~mm}$ の円柱状サンプルを作製し た後, 表面をエメリー紙＃600で研磨した。なお，これらの 引張試験片および水素量測定用試験片はいずれも, 各熱処 理後の棒材から, 棒材の中心軸と試験片の中心軸が一致す るように採取したものである。

\section{$2 \cdot 2$ 実験方法}

\section{$2 \cdot 2 \cdot 1$ ミクロ組織観察}

棒材長手方向に平行な断面を切断, 研磨し, シュウ酸 電解腐食を行った後, 中心部のミク口組織を光学顕微鏡 にて観察した。また, 電解研磨にて薄膜試料を作製し, 透 過型電子顕微鏡 (Transmission electron microscope：TEM, Hitachi-HF-2000）にて，時効処理により析出した炭化物の 観察打よび同定を行った。

$2 \cdot 2 \cdot 2$ 水素チャージ

引張試験片打よび水素量測定用試験片を高温・高圧水 素ガス中に曝露して, 鋼材内部に水素を侵入させた。い ずれの試験片に対しても, 曝露条件は圧力 $100 \mathrm{MPa}$, 温度

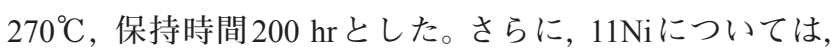
侵入水素量が水素脆化挙動に及ぼす影響を調查するため, 圧力 $0.7 \mathrm{MPa}$ 抢よび $10 \mathrm{MPa}$ においても同様の水素チャージ を行った。なお, 以上の水素チャージ条件に打いて, 本研 究で用いる全ての試験片には中心部まで水素が飽和し, 濃 度分布が均一になることを確認済みである ${ }^{17)}$

$2 \cdot 2 \cdot 3$ 水素放出プロファイルの測定

ガスクロマトグラフィ方式の昇温脱離分析 (Thermal desorption analysis：TDA）を用いて, 水素チャージした円 柱状サンプル（Fig.1（b)）からの水素放出プロファイルを 取得した。昇温速度は $100^{\circ} \mathrm{C} / \mathrm{hr}$, 測定開始温度は室温 $\left(25^{\circ} \mathrm{C}\right.$ 付近), 最高到達温度は $800^{\circ} \mathrm{C}$, 分析周期は $5 \mathrm{~min} と し$, 侵入 水素量打よびVCによる水素トラップ効果を調查した。 $2 \cdot 2 \cdot 4$ 低ひずみ速度引張試験

$\gamma$ 鋼を含む鉄鋼材料では, ひずみ速度が小さいほど引張
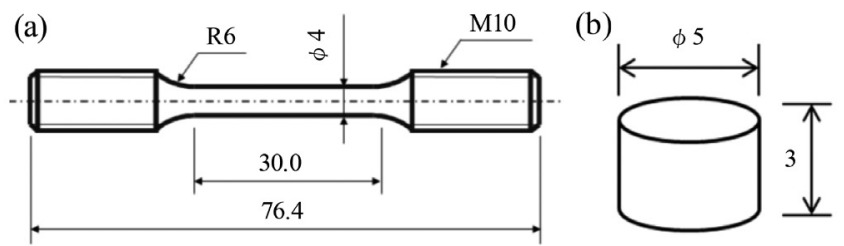

Fig. 1. Shapes and dimensions of the specimens for (a) tensile test and (b) measurement of hydrogen concentration. 
特性への水素の影響が顕著となることが知られている ${ }^{18)}$ そこで本研究では，水素チャージおよび未チャージ試験片 のいずれに対しても，低ひずみ速度引張 (Slow strain-rate tensile: SSRT) 試験を行った。すべての試験に打いて, 試験 環境は室温・大気中とし, クロスヘッドスピードは 0.002 $\mathrm{mm} / \mathrm{s}$ （初期ひずみ速度 $0.67 \times 10^{-4} / \mathrm{s}$ ）とした。

$2 \cdot 2 \cdot 5$ 破面観察

引張試験後の破面観察には, 走査型電子顕微鏡 (Scanning electron microscope : SEM, Hitachi-S4800 およびSU1510)を 用いた。また，破壞形態への水素の影響を定量化するため， 破面上のディンプル破面の面積率を測定した。計測に際し ては，まず破面中央部の $300 \mu \mathrm{m} \times 200 \mu \mathrm{m}$ の範囲で撮像し た。その後, SEM像内でディンプル破面を呈している箇所 と，そうでない平滑な箇所を画像解析ソフトWinROOFに て二值化し, 前者の面積率をディンプル破面率として算出 した。

\section{$2 \cdot 2 \cdot 6$ 破断試験片の解析}

SSRT 試験後の $7 \mathrm{Ni}-\mathrm{PA}$ 材と $11 \mathrm{Ni}-\mathrm{PA}$ 材に対し，内部き裂 (破面の形成には直接寄与せず, 試験片中に残存した微視 き裂）の分析を行って破壊メカニズムを検討した。観察に あたっては, 破断した水素未チャージ材打よび水素チャー ジ材 (チャージ条件： $100 \mathrm{MPa}, 270^{\circ} \mathrm{C}, 200 \mathrm{hr}$ ) の試験片を 長手方向断面に沿って切断し，エメリ一紙，ダイヤモンド ペースト, コロイダルシリカを用いて研磨を施した後, 電 界放出型SEM（JEOL，JSM-7001FKM）を用いて内部き裂 を観察し, EBSD (Electron Backscettered Diffraction) 法にて その周囲の結晶方位解析を行った。EBSD解析に打ける加 速電圧は $20 \mathrm{kV}$, 電子ビームのステップサイズは $50 \mathrm{~nm}$ と した。

また，破断時における変形組織（転位や変形双晶）をよ り詳細に分析するため, EBSDの解析に用いた水素チャー
ジ材の試料から，破断部近傍（破面直下 $100 \mu \mathrm{m}$ 以内）にあ る粒界を含む領域を収束イオンビーム加工（FIB）法にて 採取し，TEM観察に供した。

\section{3. 実験結果}

\section{$3 \cdot 1$ ミクロ組織}

Fig.2に, 光学顕微鏡による $7 \mathrm{Ni}$ および $11 \mathrm{Ni}$ のミクロ組織 観察写真を示す。平均結晶粒径はいずれも50 $\mu \mathrm{m}$ 程度であ り, 鋼種, 熱処理条件による光学顕微鏡組織への影響は認 められなかった。

Fig.3に，時効処理後における $7 \mathrm{Ni}$ および $11 \mathrm{Ni}$ の TEM観 察写真を示す。7Niおよび $11 \mathrm{Ni}$ ともに, UA材に打いて析出 粒子は認められなかった。ただし, As-STよりも硬さは上 昇していることから (Table 2), UA 材ではVC粒子となる 前段階の微細な VCクラスターが形成されており, これが 硬さ上昇に寄与したものと推察する。一方，PA材と $\mathrm{OA}$ 材 ではナノオーダーの析出粒子が多数認められた。電子線回 折により, これらの粒子は格子定数 $0.42 \mathrm{~nm}$ の面心立方構 造であることが確認された。C欠陥を含む $\mathrm{VC}$ は格子定数 0.41 0.42 nmのB 1 構造であることが報告されており ${ }^{199)}$, 本研究で観察された析出物も VCであると同定される。 Fig.4に, TEM観察により確認したVCの粒子径分布および 平均粒子径: $\bar{d}$ を示す。 $7 \mathrm{Ni}$ 打よび $11 \mathrm{Ni}$ ともに, PA材より も OA材において粒子サイズの大きなVCが多く分散して おり，平均粒子径は $7 \mathrm{Ni}$ の $\mathrm{PA}$ 材と $\mathrm{OA}$ 材でそれでれ約 $9 \mathrm{~nm}$ と約 $10 \mathrm{~nm}, 11 \mathrm{Ni}$ のA材とOA材でそれぞれ約 $9 \mathrm{~nm}$ と約 13 nmであった。11Niに打いて7Niよりも僅かに粒子径が大き い傾向にあるのは, $\gamma$ マトリクス中の $\mathrm{Ni}$ 濃度の増大が $\mathrm{C}$ 固

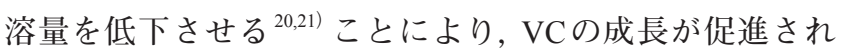
たためと考える。
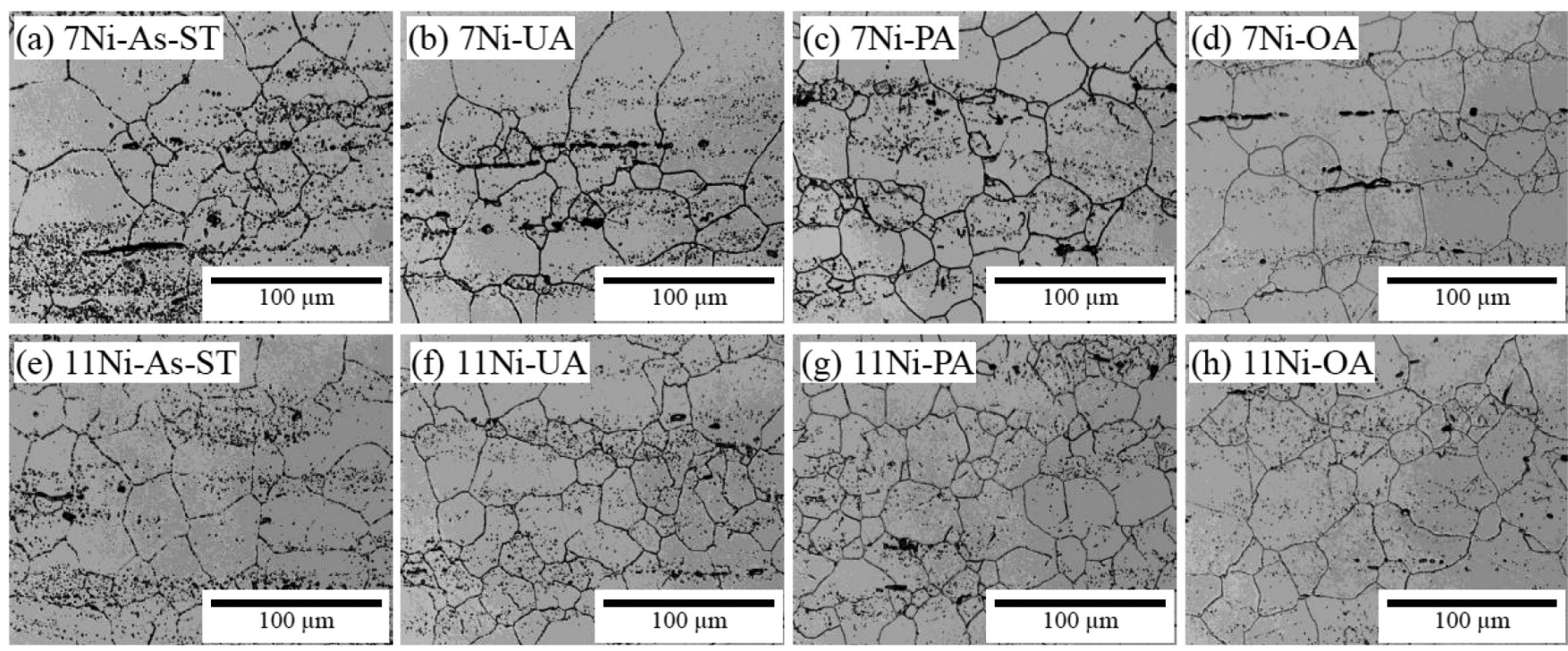

Fig. 2. Optical microscope images of the initial microstructures of (a) (d) 7Ni and (e) (h) 11Ni under (a)(e) As-ST, (b)(f) UA, (c)(g) PA and (d)(h) OA conditions. 


\section{$3 \cdot 2$ 侵入水素量および水素放出プロファイル}

Table 3 に, $7 \mathrm{Ni}$ 打よび $11 \mathrm{Ni} に$ 打ける水素チャージ後の 侵入水素量を示す。水素ガス圧力 $100 \mathrm{MPa}$ に打いて, 侵入 水素量は $7 \mathrm{Ni}$ 打よび $11 \mathrm{Ni}$ ともに熱処理状態に関係なく90 mass ppm程度となっており, $\mathrm{Ni}$ 含有量の違いによる差は認 められなかった。また，11Niについては水素ガス圧力を 10

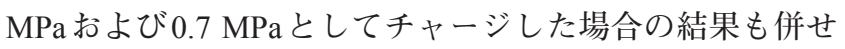
て示しているが，ここでも熱処理状態の違いによる顕著な 差は認められず，侵入水素量はそれぞれ，30 mass ppm と6 mass ppm程度であった。水素ガス環境に打ける材料中への 熱平衡 (飽和) 水素濃度 $C_{\mathrm{s}}$ は, Sieverts則に従って, 固溶度 $S$ とフガシティfを用いて次式（1）で表される。

$$
\begin{aligned}
& C_{\mathrm{s}}=S \sqrt{f} \cdots \\
& \text { また，フガシティfは次のように表される。 } \\
& f=p \cdot \exp (p b / R T) \cdot
\end{aligned}
$$

ここで, $p$ は水素ガス圧力 $(\mathrm{MPa}), T$ は絶対温度 $(\mathrm{K})$, $b=1.584 \times 10^{-5} \mathrm{~m}^{3} / \mathrm{mol}, R$ は気体定数 $(8.314 \mathrm{~J} /(\mathrm{mol} \cdot \mathrm{K}))$ である。bには Marchi らの報告 ${ }^{22)}$ にある值を用いた。Fig.5 に示す通り，いずれの材料においても測定した飽和水素量 はフガシティ $f$ の平方根に概ね比例しており, 飽和水素量

Table 3. Hydrogen content (mass ppm) in $7 \mathrm{Ni}$ and $11 \mathrm{Ni}$ after hydrogen-charging at $270^{\circ} \mathrm{C}$ for $200 \mathrm{hr}$.

\begin{tabular}{l|l|c|c|c}
\hline \multirow{3}{*}{ Material } & \multirow{2}{*}{ Acronym } & \multicolumn{3}{|c}{ Pressure of hydrogen gas exposure } \\
\cline { 3 - 5 } & & $100 \mathrm{MPa}$ & $10 \mathrm{MPa}$ & $0.7 \mathrm{MPa}$ \\
\hline \multirow{4}{*}{$7 \mathrm{Ni}$} & As-ST & 97.9 & - & - \\
\cline { 2 - 5 } & UA & 95.7 & - & - \\
\cline { 2 - 5 } & PA & 96.5 & - & - \\
\cline { 2 - 5 } & OA & 83.6 & - & - \\
\hline \multirow{3}{*}{$11 \mathrm{Ni}$} & As-ST & 93.6 & 26.4 & 4.9 \\
\cline { 2 - 5 } & UA & 82.4 & 28.1 & 4.7 \\
\cline { 2 - 5 } & PA & 91.0 & 32.0 & 5.8 \\
\cline { 2 - 5 } & OA & 73.8 & 29.3 & 8.2 \\
\hline
\end{tabular}
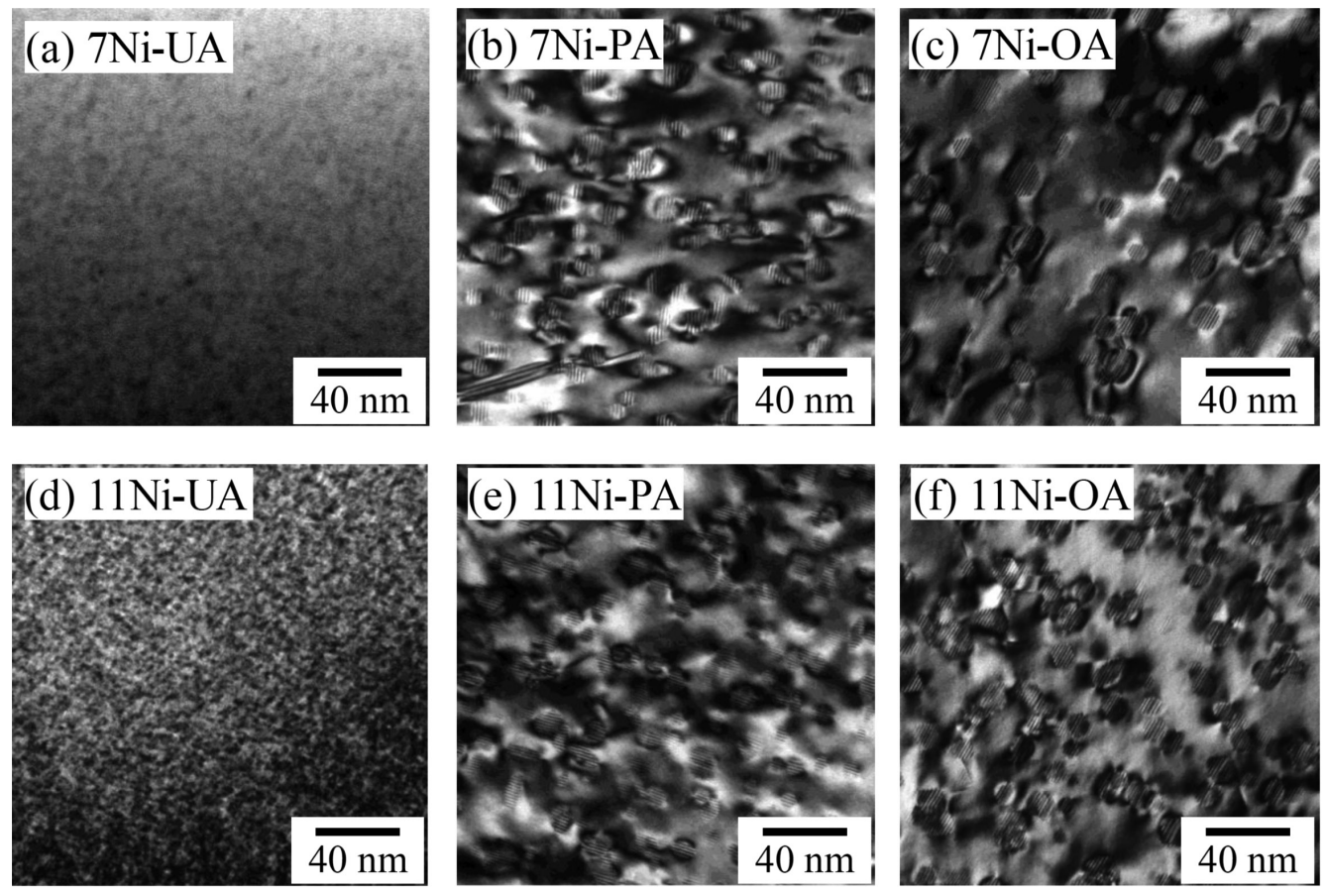

Fig. 3. TEM images of the initial microstructures of (a) (c) 7Ni and (d) (f) $11 \mathrm{Ni}$ under (a)(d) UA, (b)(e) PA and (c)(f) OA conditions.
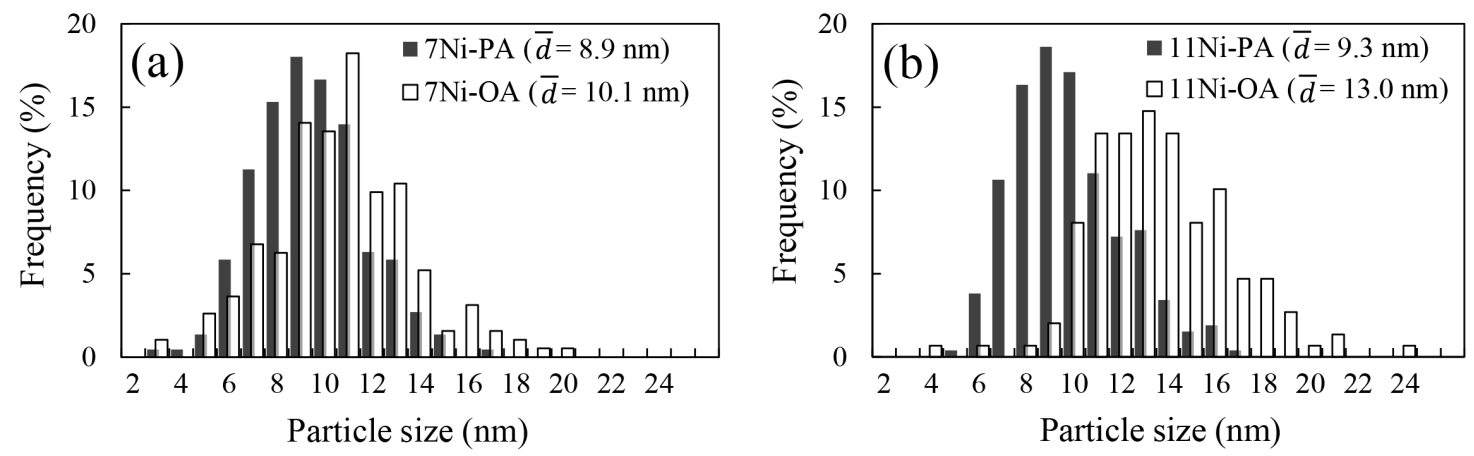

Fig. 4. Distributions of VC particle size in (a) $7 \mathrm{Ni}$ and (b) $11 \mathrm{Ni}$ under PA and OA conditions. 
はSieverts則に準じていることが分かる。

Fig.6に，7Ni 打よび11Niに打ける TDA水素放出プロ ファイルを，熱処理条件ごとに色分けして示す。いずれの プロファイルに拀いても, $400^{\circ} \mathrm{C}$ 近傍に水素放出速度の第 一ピークが認められる。この第一ピークは，全ての供試材 に共通して存在する $\gamma$ マトリクス中の格子間サイトや結晶 粒界等に分布していた水素によるものであると考えられ

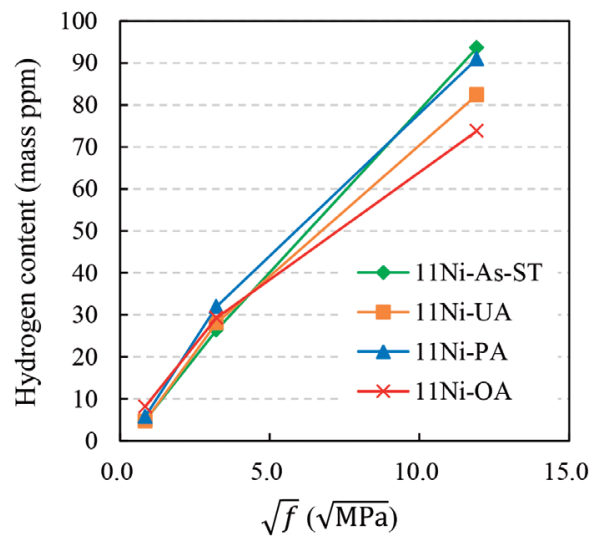

Fig. 5. Relationship between square root of hydrogen gas fugacity and resultant hydrogen content in $11 \mathrm{Ni}$ under different conditions of VC precipitates. (Online version in color.)
る。さらに，7Niおよび $11 \mathrm{Ni}$ ともにPA材および $\mathrm{OA}$ 材では, いずれの水素チャージ条件下でも高温側 $\left(500 \sim 550^{\circ} \mathrm{C}\right.$ 付近 $)$ のプロファイルにショルダー，あるいは明確な第二ピー クが認められた。TEM観察では，PA材およびOA材のみで $\mathrm{VC}$ 粒子が観察された（Fig.3）ことから，この高温側のピー クは主として VC粒子にトラップされた水素の放出による ものであることを示唆している。

\section{$3 \cdot 3$ 応力-ひずみ特性および延性低下挙動}

Fig.7およびFig.8にそれぞれ，7Niおよび11NiのSSRT試 験結果を示す。罒中には, 破断後の試験片を用いて TDAに より測定した侵入水素量 $C_{\mathrm{H}, \mathrm{R}}$ も示している。さらに $11 \mathrm{Ni}$ については，水素チャージ時の圧力を $100 \mathrm{MPa}, 10 \mathrm{MPa}$, および $0.7 \mathrm{MPa}$ と変化させた場合の結果も併せて示す。ま た Table 4 には, SSRT試験で測定された各材料の引張強さ (Tensile strength：TS) と絞り值 (Reduction of area：RA) に 加えて, 水素脆化の指標である相対絞り（Relative reduction of area：RRA, 水素チャージ材の絞りを水素未チャージ材 の絞りで除した值) をまとめて示す。

水素未チャージ材の場合, 各々の熱処理状態に打いて, 鋼種間での強度, 破断伸び, 絞りにほとんど差は認められ なかった。PA材およびOA材における TEM観察では, $7 \mathrm{Ni}$ よりも $11 \mathrm{Ni}$ の方が僅かにVC粒子が大きい傾向にあった
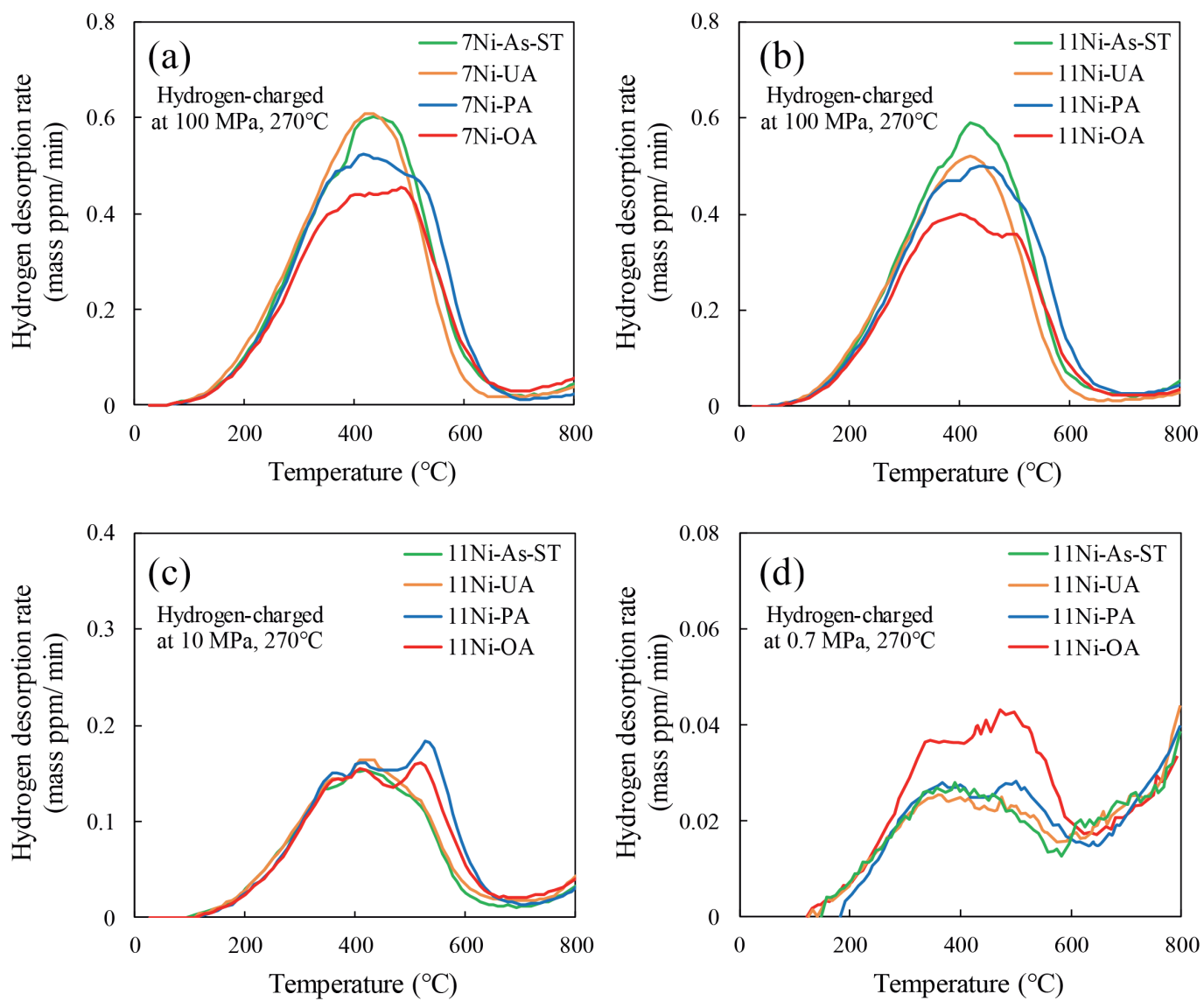

Fig. 6. Hydrogen desorption spectra from the hydrogen-charged specimens of $7 \mathrm{Ni}$ and $11 \mathrm{Ni}$ under different heat treatment conditions. (a) $7 \mathrm{Ni}$ charged at $100 \mathrm{MPa}, 270^{\circ} \mathrm{C}$, (b) $11 \mathrm{Ni}$ charged at $100 \mathrm{MPa}, 270^{\circ} \mathrm{C}$, (c) $11 \mathrm{Ni}$ charged at $10 \mathrm{MPa}, 270^{\circ} \mathrm{C}$ and (d) $11 \mathrm{Ni}$ charged at $0.7 \mathrm{MPa}, 270^{\circ} \mathrm{C}$. (Online version in color.) 

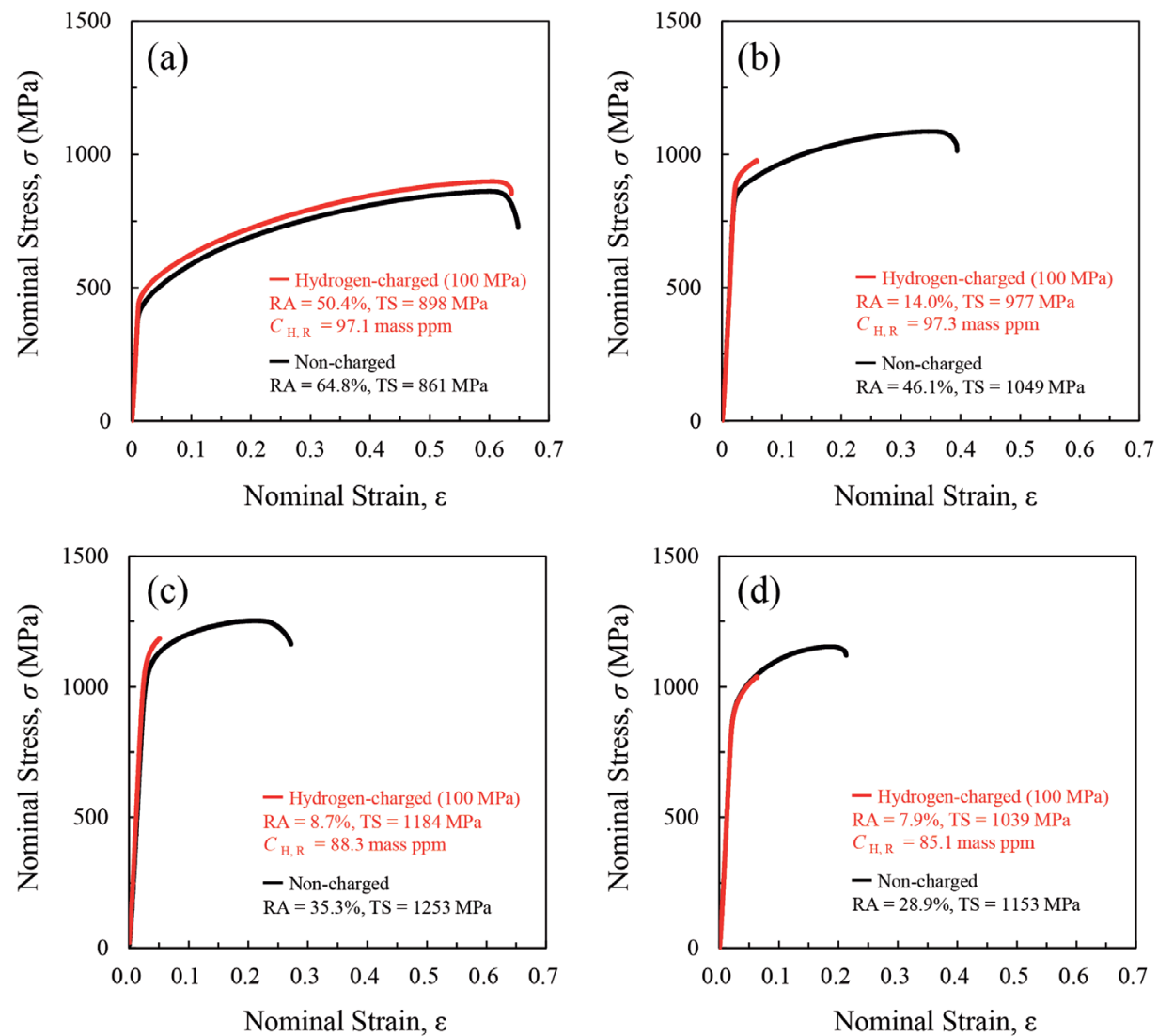

Fig. 7. Nominal stress-nominal strain curves of non-charged (black curves) and hydrogen-charged (red curves) 7Ni under (a) As-ST, (b) UA, (c) PA and (d) OA conditions. (Online version in color.)
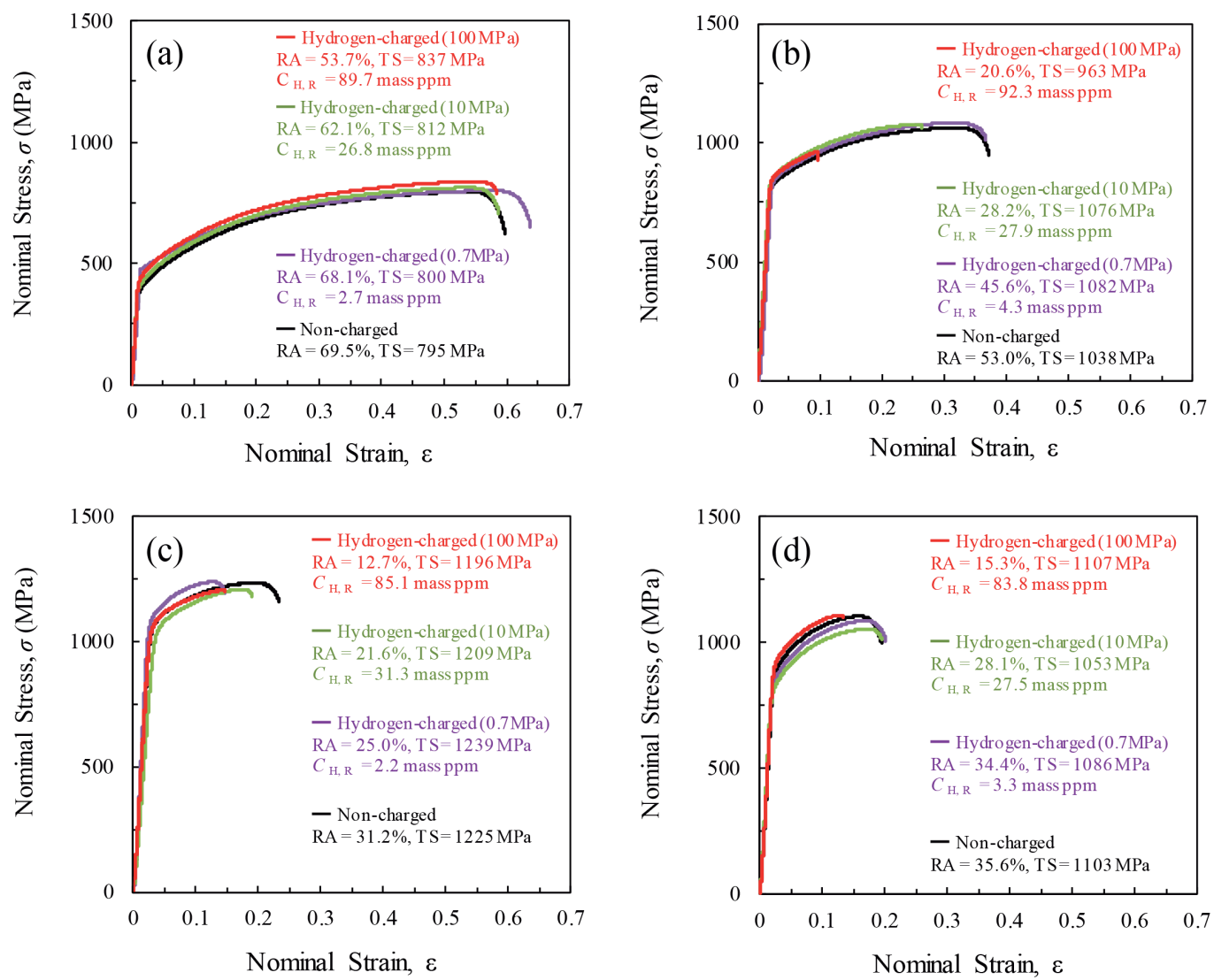

Fig. 8. Nominal stress-nominal strain curves of non-charged (black curves) and hydrogen-charged (colored curves) 11Ni under (a) AsST, (b) UA, (c) PA and (d) OA conditions. (Online version in color.) 
が，この違いは引張特性に有意な影響を与えるものではな かった。7Niおよび11NiのPA材は，双方とも $1200 \mathrm{MPa}$ 超える引張強さを示した。

Fig.9に，7Ni および11NiにおけるRRAと，Imade ${ }^{11)} お$ よびTajima $~^{12)}$ が報告した, 高温・高圧水素ガス曝露によ る水素チャージ後のSUH660（析出硬化状態で引張強さは 約 $1100 \mathrm{MPa}$ ）のRRAを合せて示す。曝露圧力 $100 \mathrm{MPa}$ の 場合，7Ni および11Niにおいては，いずれの時効状態にお いても水素未チャージ状態より絞り值が低下し，RRAは $7 \mathrm{Ni}$ において約 $0.3 ， 11 \mathrm{Ni}$ に打いて約 0.4 となった。RRAは

Table 4. Summary of the tensile properties of $7 \mathrm{Ni}$ and $11 \mathrm{Ni}$ under different heat treatment conditions.

\begin{tabular}{|c|c|c|c|c|c|}
\hline Material & Acronym & $\begin{array}{l}\text { Pressure of } \\
\text { hydrogen } \\
\text { gas-exposure }\end{array}$ & $\begin{array}{c}\text { Tensile } \\
\text { strength } \\
\text { (MPa) }\end{array}$ & $\begin{array}{c}\text { Reduction of } \\
\text { area } \\
(\%)\end{array}$ & RRA \\
\hline \multirow{8}{*}{$7 \mathrm{Ni}$} & \multirow{2}{*}{ As-ST } & Non-charged & 861 & 64.8 & - \\
\hline & & $100 \mathrm{MPa}$ & 898 & 50.4 & 0.78 \\
\hline & \multirow{2}{*}{ UA } & Non-charged & 1049 & 46.1 & - \\
\hline & & $100 \mathrm{MPa}$ & 977 & 14.0 & 0.30 \\
\hline & \multirow{2}{*}{ PA } & Non-charged & 1253 & 35.3 & - \\
\hline & & $100 \mathrm{MPa}$ & 1184 & 8.7 & 0.25 \\
\hline & \multirow{2}{*}{$\mathrm{OA}$} & Non-charged & 1153 & 28.9 & - \\
\hline & & $100 \mathrm{MPa}$ & 1039 & 7.9 & 0.27 \\
\hline \multirow{16}{*}{$11 \mathrm{Ni}$} & \multirow{4}{*}{ As-ST } & Non-charged & 795 & 69.5 & - \\
\hline & & $100 \mathrm{MPa}$ & 837 & 53.7 & 0.77 \\
\hline & & $10 \mathrm{MPa}$ & 812 & 62.1 & $\begin{array}{l}0.89 \\
\end{array}$ \\
\hline & & $0.7 \mathrm{MPa}$ & 800 & 68.0 & 0.98 \\
\hline & \multirow{4}{*}{ UA } & Non-charged & 1038 & 53.0 & - \\
\hline & & $100 \mathrm{MPa}$ & 963 & 20.6 & 0.39 \\
\hline & & $10 \mathrm{MPa}$ & 1076 & 28.2 & 0.53 \\
\hline & & $0.7 \mathrm{MPa}$ & 1082 & 45.6 & 0.86 \\
\hline & \multirow{4}{*}{ PA } & Non-charged & 1225 & 31.2 & - \\
\hline & & $100 \mathrm{MPa}$ & 1196 & 12.7 & 0.41 \\
\hline & & $10 \mathrm{MPa}$ & 1209 & 21.6 & 0.69 \\
\hline & & $0.7 \mathrm{MPa}$ & 1239 & 25.0 & 0.80 \\
\hline & \multirow{4}{*}{$\mathrm{OA}$} & Non-charged & 1103 & 35.6 & - \\
\hline & & $100 \mathrm{MPa}$ & 1107 & 15.3 & 0.43 \\
\hline & & $10 \mathrm{MPa}$ & 1053 & 28.1 & 0.79 \\
\hline & & $0.7 \mathrm{MPa}$ & 1086 & 34.4 & 0.97 \\
\hline
\end{tabular}

$11 \mathrm{Ni}$ の方が $7 \mathrm{Ni} よ り も$ 高く, 水素による延性の低下は軽度 であった。なお，引張強さに関しては，水素侵入による低 下量はいずれも $10 \%$ 未満であり，顕著な水素の影響は認 められなかった。同様の試験において, SUH660のRRAは $C_{\mathrm{H}, \mathrm{R}}=37$ mass ppmの下で 0.55 程度 ${ }^{11)}, C_{\mathrm{H}, \mathrm{R}}=67$ mass ppm の下で 0.52 程度 ${ }^{12)}$ である。Fig. 10 に, $11 \mathrm{Ni}$ と SUH660 ${ }^{11,12)}$ に おける $C_{\mathrm{H}, \mathrm{R}}$ とRRAの関係を比較する。11Niではいずれも 内部水素量の増大に伴って RRAが低下したが，As-ST材の RRA は，時効材よりも高位に推移した。また，As-ST材お よび時効材のいずれも $C_{\mathrm{H}, \mathrm{R}}$ が小さければ延性低下を比較的 軽度に留めることができるが, UA材やPA材では0.7 MPa チャージで侵入させた僅か 3 mass ppmの水素でも延性が 低下した。ただし，図中に示す通り，11Ni時効材における $C_{\mathrm{H}, \mathrm{R}}$ とRRAの関係は析出硬化した SUH660 と同程度であ り，同量の水素が侵入した場合の水素脆化感受性は両者で ほぼ同等であると言える。

\section{$3 \cdot 4$ 破面形態}

Fig.11 およびFig.12にそれぞれ，水素チャージ有無にお ける $7 \mathrm{Ni} と 11 \mathrm{Ni}$ の破面中央部の $\mathrm{SEM}$ 像と，これらの破面 像から求めたディンプル破面率を示す。水素未チャージ の場合，7Ni および $11 \mathrm{Ni}$ の As-ST材ではともにほぼ全面が

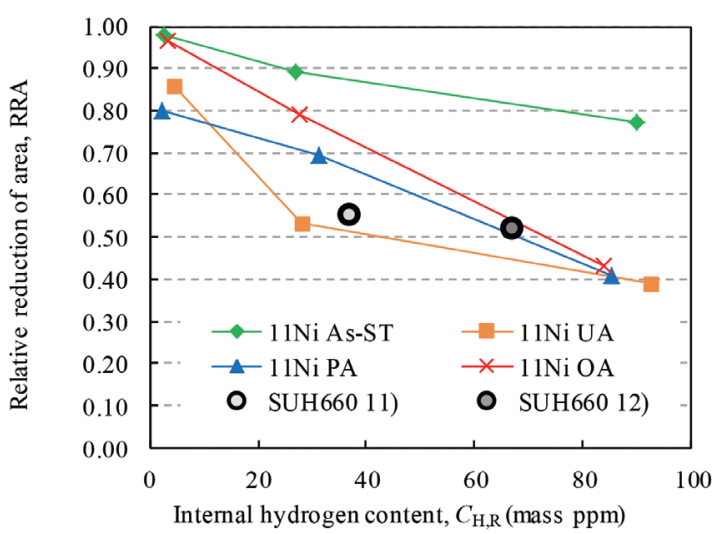

Fig. 10. Relative reduction of area (RRA) of $11 \mathrm{Ni}$ and agehardened SUH660 ${ }^{11,12}$ as a function of internal hydrogen content, $C_{\mathrm{H}, \mathrm{R}}$. (Online version in color.)

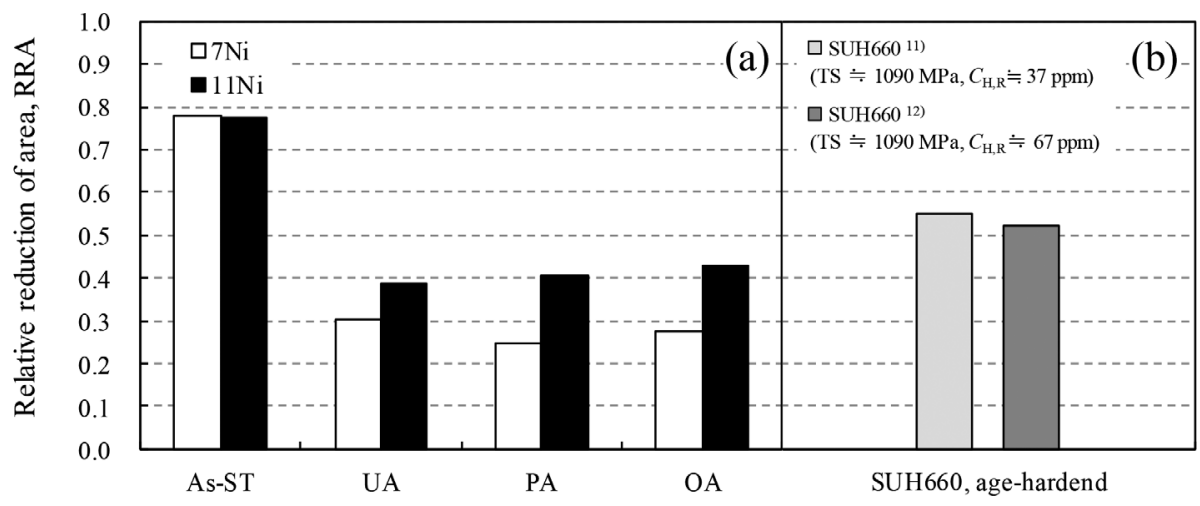

Fig. 9. Relative reduction of area (RRA) of (a) $7 \mathrm{Ni}$ and $11 \mathrm{Ni}$ (hydrogen-charged at $100 \mathrm{MPa}, 270^{\circ} \mathrm{C}$ ) as well as (b) age-hardened SUH660 $0^{11,12)}$. 
ディンプル破面となっていた。一方, 時効材ではAs-ST材 よりもディンプル破面率が減少して平滑な破面が多く認め られ, $\mathrm{Ni}$ 含有量の少ない7Niにおいて, 平滑な破面の出現 はより顕著な傾向にあった。100 $\mathrm{MPa}, 270^{\circ} \mathrm{C} に$ おいて水素 チャージを施した場合, As-ST材でも平滑破面が認められ るようになり, 時効材に揸いてはディンプル破面率が水素 未チャージの場合よりも低くなった。すなわち, 時効処理 で生成したVCクラスターやVC粒子による材料の高強度 化と内部水素の存在はいずれも, 引張破断における平滑破 面の形成を促す傾向にあった。平滑な破面は, 粒界破壊, あるいは粒内破壞（へき開破壞や擬へき開破壞）によって 表れる。平滑破面上を拡大観察すると, Fig.13に示すとお
り，へき開，擬へき開破壊の特徵であるリバーパターン等 は認められず，これらは粒界破壊によって生じた破面と考 えられる。また, 破面上にはサブミクロンオーダーの微小 ボイドが無数に認められた。

上記の平滑破面の形成要因を明らかにするため, 7Ni-PA 材および $11 \mathrm{Ni}-\mathrm{PA}$ 材の破断試験片の縦断面を観察したとこ ろ, 水素チャージ有無いずれの場合においても, 破面直下 には複数の内部き裂が認められた。これら内部き裂近傍を SEMにより観察した結果を, Fig.14に示す。いずれも，き 裂先端近くに, 粒界に沿ったマイクロボイドの存在が確認 された。次に, 内部き裂近傍を EBSDにて解析 (ステップサ イズは $50 \mathrm{~nm}$ ) した結果を Fig.15に示す。各材料について,

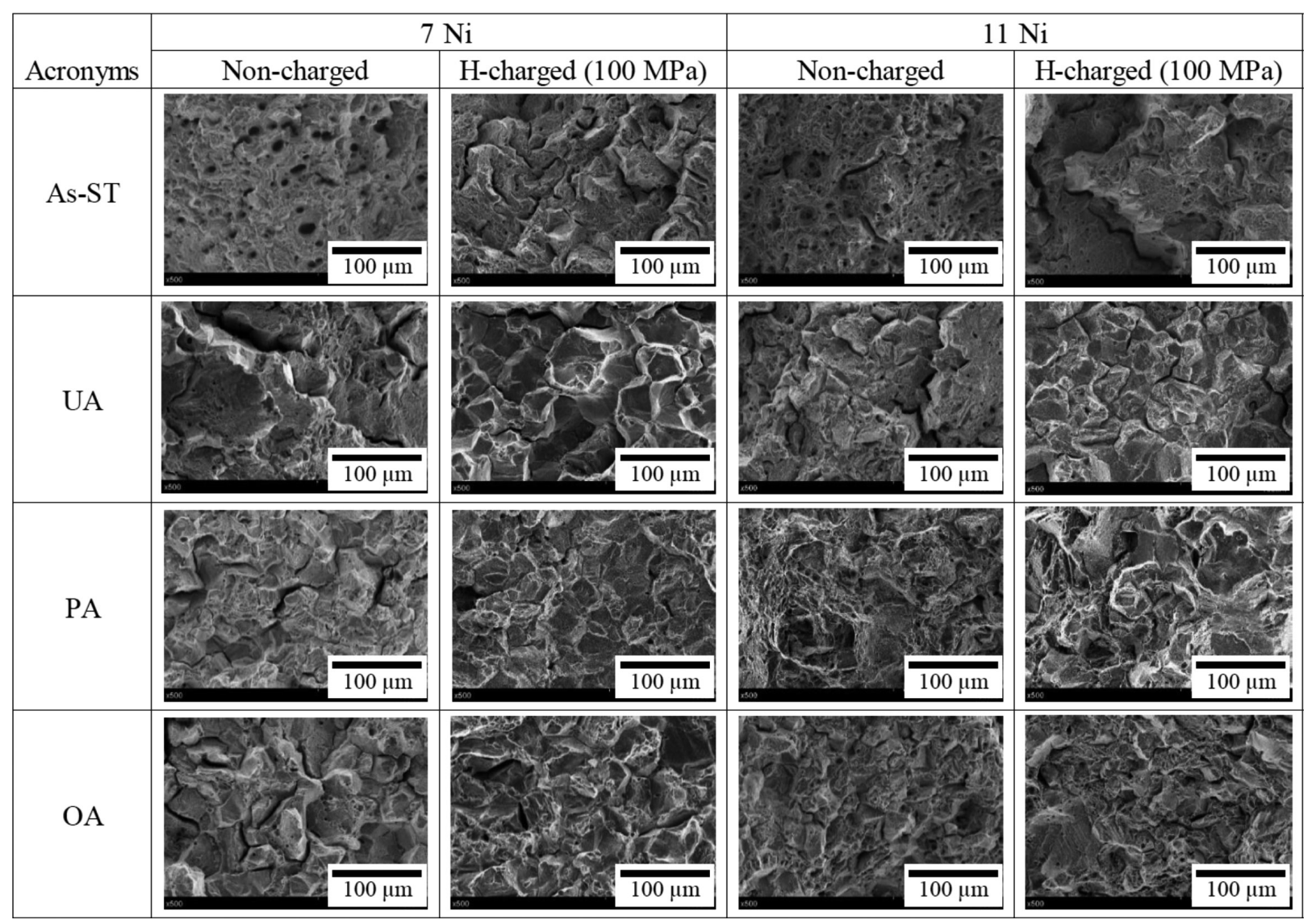

Fig. 11. SEM micrographs of the fracture surfaces of $7 \mathrm{Ni}$ and $11 \mathrm{Ni}$ under non-charged and hydrogen-charged $\left(100 \mathrm{MPa}, 270^{\circ} \mathrm{C}\right)$ conditions.
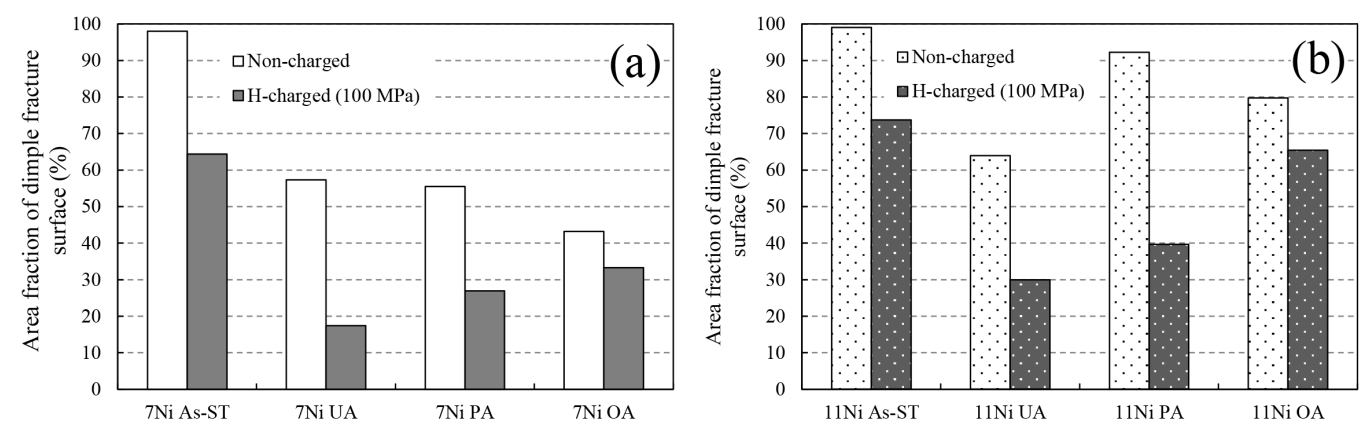

Fig. 12. Area fractions of dimple fracture surface in (a) $7 \mathrm{Ni}$ and (b) $11 \mathrm{Ni}$ under non-charged and hydrogen-charged $\left(100 \mathrm{MPa}, 270^{\circ} \mathrm{C}\right)$ conditions. 
結晶方位 (Inverse pole figure: IPF) マップ, 変形双晶を可視 化するために $\sum 3$ 双晶界面を赤色でトレースしたイメー ジクオリティ（IQ）マップ，および相分布マップを示して いる。水素チャージの有無に関わらず，内部き裂は粒界に 沿って発生・進展していることが判明した。以上のSEM 観察とEBSDによる解析結果から, 内部き裂は粒界上に生 成したマイクロボイドに沿って発生・進展し, その結果, 粒界破壊に至ると推定され, 破面観察にて認められた微小 ボイドを伴う平滑破面は，この過程にて生じた粒界破壊の 痕跡であったと考えられる。また, 各々のき裂を挟む結晶
粒内にはすべり帯が認められ，11Niにおいては粒界へと衝 突した明瞭な複数の変形双晶も認められた。なお, 相分布 マップに示す通り, 加工誘起マルテンサイトの存在はいず れの場合にも認められなかった。

\section{$3 \cdot 5$ 粒界近傍における変形下部組織}

Fig.11 およびFig.14，15の結果から，7Niと 11Niの時効材 では水素未チャージの場合でも粒界破壊が生じており, 水 素チャージした場合には, その頻度がさらに上昇すること が判った。したがって, 本研究に用いた析出強化型高 $\mathrm{Mn}-\gamma$ 鋼は時効状態において, 内部水素の有無に関係なく粒界破
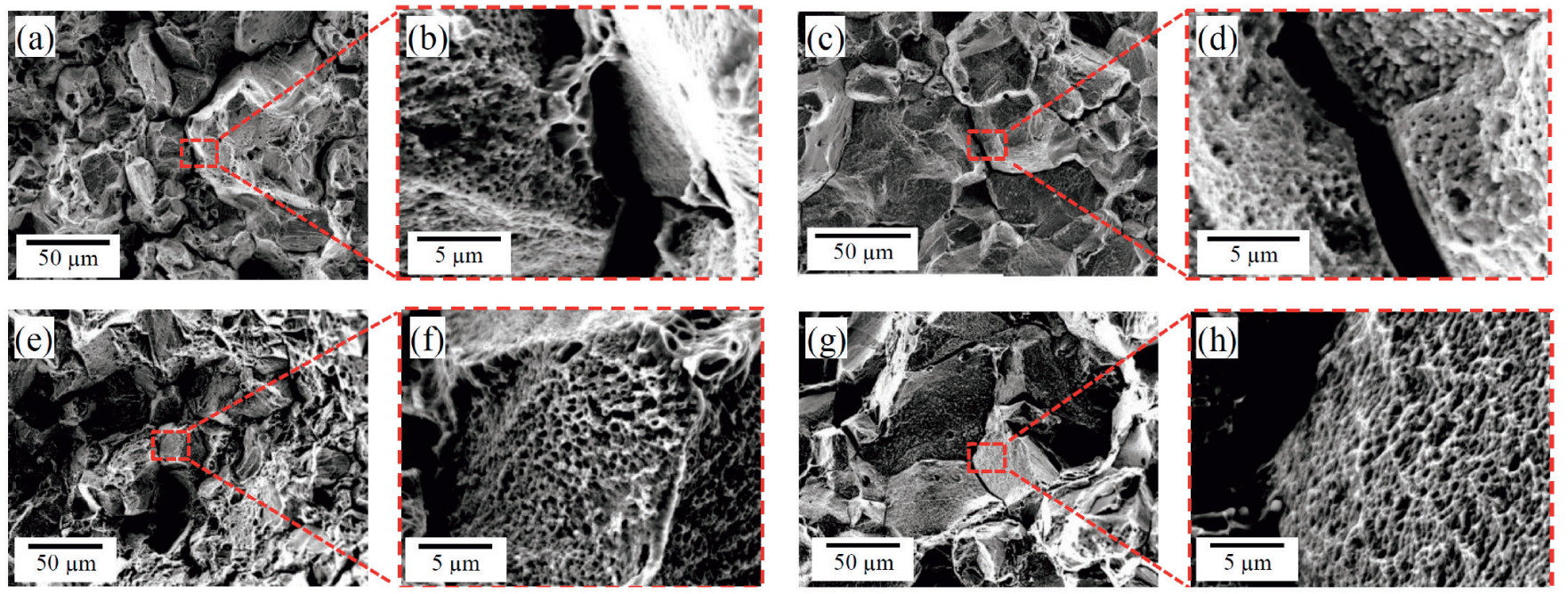

Fig. 13. SEM images of the fracture surfaces of (a) (d) 7Ni-PA and (e) (h) 11Ni-PA : (a)(b) non-charged 7Ni-PA ; (c)(d) hydrogencharged $\left(100 \mathrm{MPa}, 270^{\circ} \mathrm{C}\right) 7 \mathrm{Ni}-\mathrm{PA}$; (e)(f) non-charged $11 \mathrm{Ni}-\mathrm{PA}$; $(\mathrm{g})(\mathrm{h})$ hydrogen-charged $\left(100 \mathrm{MPa}, 270^{\circ} \mathrm{C}\right) 11 \mathrm{Ni}-\mathrm{PA}$. (Online version in color.)
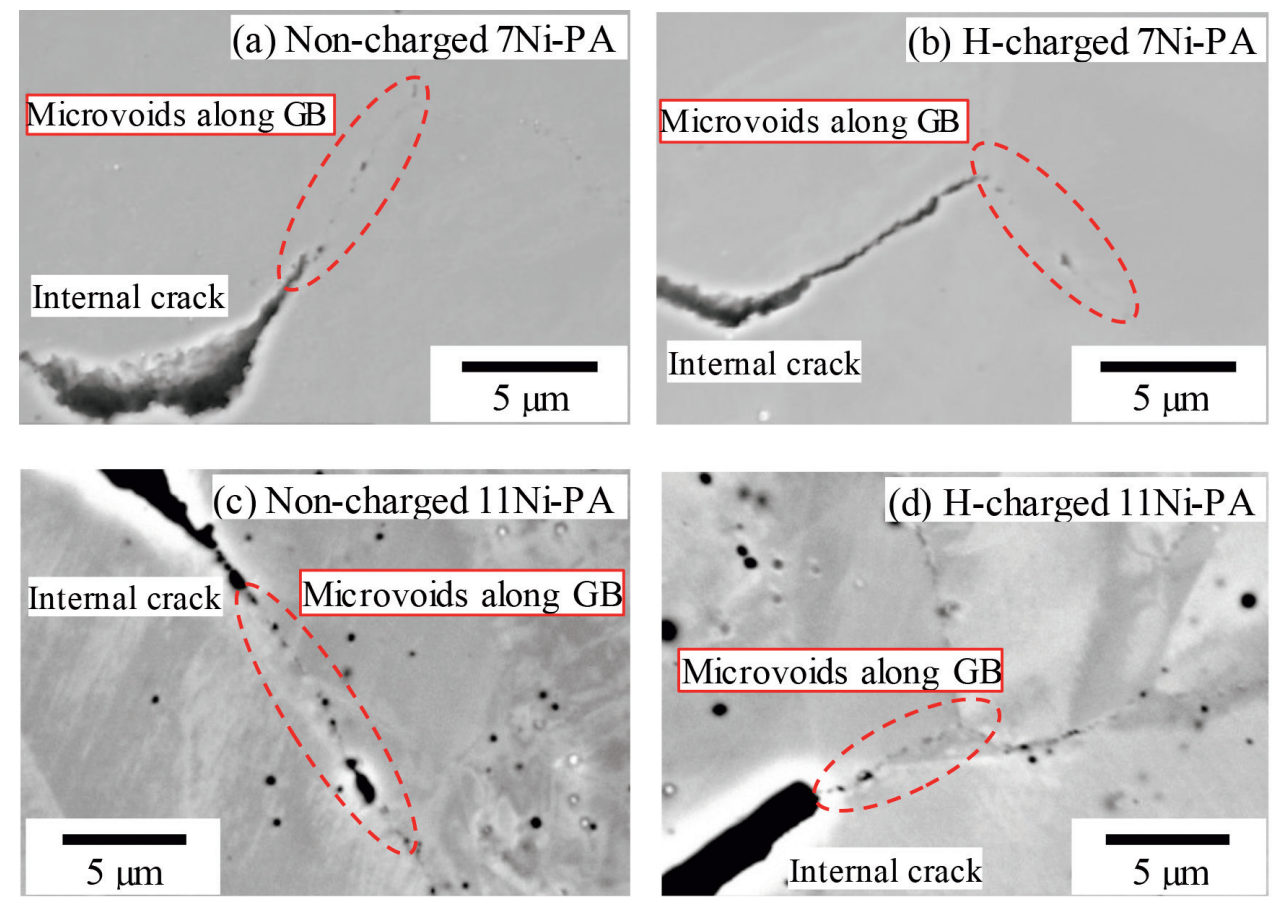

Fig. 14. SEM images around the internal cracks in (a) non-charged $7 \mathrm{Ni}-\mathrm{PA}$, (b) hydrogen-charged $\left(100 \mathrm{MPa}, 270^{\circ} \mathrm{C}\right) 7 \mathrm{Ni}-\mathrm{PA}$, (c) noncharged $11 \mathrm{Ni}-\mathrm{PA}$ and $(\mathrm{d})$ hydrogen-charged $\left(100 \mathrm{MPa}, 270^{\circ} \mathrm{C}\right) 11 \mathrm{Ni}-\mathrm{PA}$. The tensile axis corresponds to the vertical direction in each picture. (Online version in color.) 
壊を生じる材料であり, 水素はその粒界破壊のプロセスを 促進させる役割を担っているものと考えられる。この粒界 破壞の支配要因を明らかにするため，まずは7Ni-PA材と $11 \mathrm{Ni}-\mathrm{PA}$ 材の引張試験前の粒界近傍をTEMにより観察し た。その結果を Fig.16に示す。7Ni-PA材および11Ni-PA材 ともに，結晶粒内の微細なVCに加え，粒界には100〜200 $\mathrm{nm}$ 程度の塊状炭化物が析出していた。TEM内でのエネル ギー散乱X線分析（EDX）および電子線回折から，これら は $\mathrm{Cr}, \mathrm{Fe}$ ，およびVを主な構成元素とする M23C6系炭化 物であることが判明した。また, Fig.16 (b) および (d) に 示す通り，結晶粒界近傍を拡大観察すると，いずれも粒界 を跨ぐ片幅50 nm程度の無析出帯 (Precipitation-Free-Zone : PFZ）が認められた。

次に，水素チャージした7Ni-PA と $11 \mathrm{Ni}-\mathrm{PA} の$ 破断試験片 に対して，破面直下 $100 \mu \mathrm{m}$ 以内に含まれる粒界をTEMに より観察した結果を Fig.17に示す。いずれも粒界近傍には 高密度の転位が分布していたが, 加工誘起マルテンサイト は認められなかった。ただし，7Ni-PA材では11Ni-PA材と 比べて, 四中矢印で指し示す通り, 厚さ数 $10 \mathrm{~nm}$ の薄い変
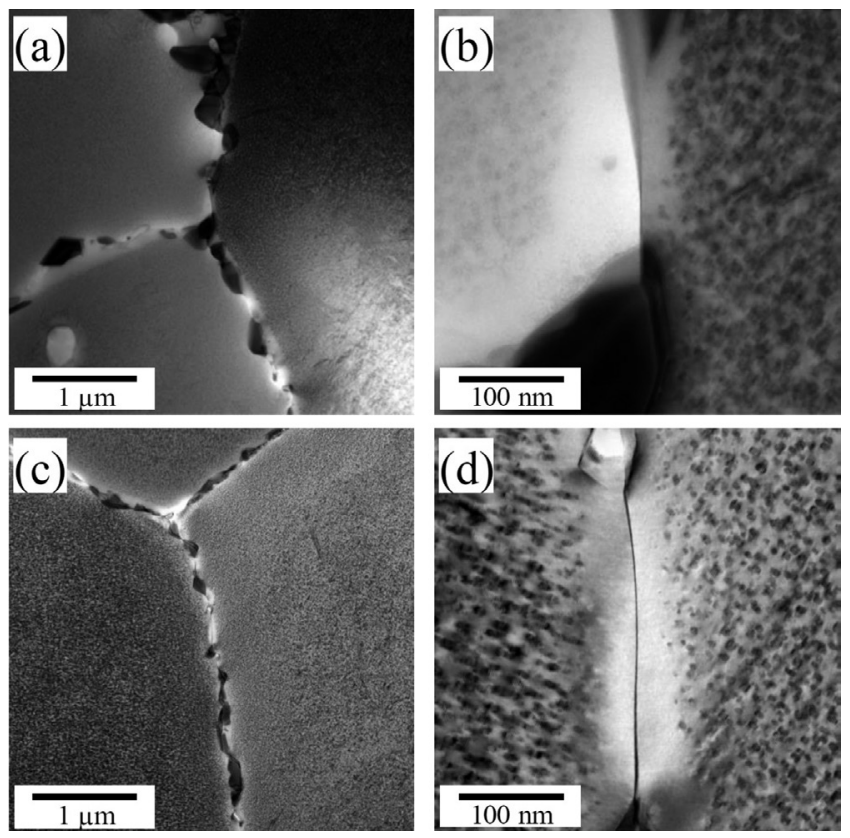

Fig. 16. TEM images of the grain boundaries in non-deformed (a)(b) $7 \mathrm{Ni}-\mathrm{PA}$ and (c)(d) 11Ni-PA: (a)(c) low- and (b)(d) high-magnification images.

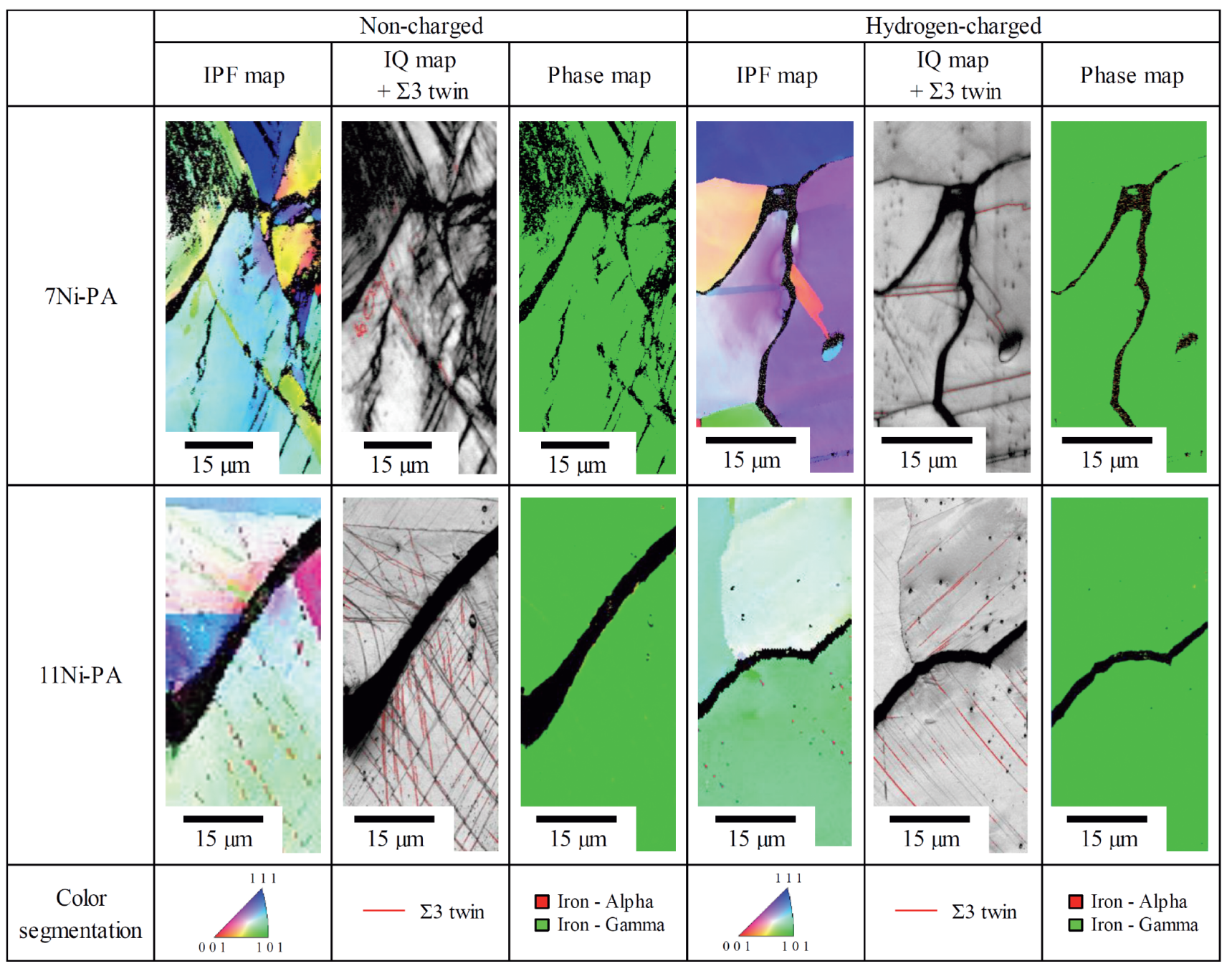

Fig. 15. EBSD images around the internal cracks in non-charged and hydrogen-charged $\left(100 \mathrm{MPa}, 270^{\circ} \mathrm{C}\right)$ specimens of $7 \mathrm{Ni}-\mathrm{PA}$ and $11 \mathrm{Ni}$-PA. The tensile axis corresponds to the vertical direction in each picture. (Online version in color.) 
形双晶がより多く認められ，そのうち幾つかは粒界へと 衝突していた。この結果はFig.15で示したEBSD観察とは 一見矛盾するが，7Ni-PA材の TEM観察で認められた変形 双晶は厚さが $50 \mathrm{~nm}$ に満たないものがほとんどであり, ス テップサイズ $50 \mathrm{~nm}$ の EBSD解析では捕捉できなかったも のと考元られる。両鋼種で認められた粒界炭化物, PFZ, そ して7Ni-PA材の粒界近傍で認められた変形双晶は, 析出硬 化型高 $\mathrm{Mn}-\gamma$ 鋼の粒界破壞発生プロセスと, 水素による粒 界破壊促進メカニズムに関与しているものと考えられ，そ れぞれの影響については後述の粒界破壊メカニズムの考察 にて言及する。

\section{4. 考察}

\section{$4 \cdot 1$ 水素未チャージ材の粒界破壊メカニズム}

析出硬化型高 $\mathrm{Mn}-\gamma$ 鋼では, 時効硬化と内部水素量の増 大に伴って, 絞り值が低下した (Table 4)。水素未チャージ 状態に打ける破壊形態は，引張強度が800 900 MPaであ る As-ST材の場合, 7Ni，11Ni ともにディンプルを伴った延 性破壊が主であった。一方，引張強さが $1000 \mathrm{MPa}$ を超える 時効材では, 粒界破壞が生じるようになった (Fig.11)。こ のように, 水素チャージを施していない状態であっても, 析出物の粒内微細分散によって高強度化させた際に, 粒界 破壊が誘起される現象は従来から多くの析出強化型合金で 確認されている。たとえば, Ohmori and Maehara ${ }^{23)}$ は $\gamma$ 系ス テンレス鋼中の $\mathrm{NbC}$ の析出, そして Ogura ${ }^{24)}$ は $\mathrm{Al}-\mathrm{Zn}-\mathrm{Mg}$ 合金中の金属間化合物の析出による粒界破壊の発生を報 告している。これらはいずれも, 析出物の微細分散によっ て粒内が強化される一方, 析出物が粒界上に偏析し, さら に粒界に沿って軟質なPFZが形成されたケースである。塑 性変形に伴って粒界析出物に転位が堆積することで, マト リクス／析出物界面に剥離が生じてマイクロボイドが生 成され, その後の塑性変形の進行に伴ってマイクロボイド
が拡大・成長することで粒界破壊に至る。また, PFZ内は 析出強化された粒内よりも相対的に強度が低いため, 塑性 変形の集中サイトとなり, マイクロボイドの生成・成長プ ロセスを助長すると考えられている。Fig.16に示した通り， $7 \mathrm{Ni}-\mathrm{PA}$ 材および11Ni-PA材ではいずれも, 結晶粒内に微 細な球状 VCが，そして粒界には $\mathrm{M}_{23} \mathrm{C}_{6}$ 系炭化物の析出と, 片幅 $50 \mathrm{~nm}$ 程度のPFZが認められた。したがって, 本研究 対象の析出硬化型 $\gamma$ 鋼に打いても, Ohmori and Maehara ${ }^{23)}$, Ogura ${ }^{24)}$ が報告したものと類似のメカニズムにて粒界破 壊が生じたものと考える。ただし, Fig.16で観察された本 研究対象材のPFZは, Ohmori and Maehara ${ }^{23)}$, Ogura ${ }^{24)}$ が 報告している片幅 $200 \mathrm{~nm}$ を超えるPFZよりも狭く, 全く 同様に変形初期から塑性変形が優先的に進行するサイト になったとは考元難い。それは，粒子径が $100 \mathrm{~nm}$ に満た ないナノ結晶材料では, 粒子内での転位運動が難しくなる こと ${ }^{25)}$ と同様に, 片幅 $50 \mathrm{~nm}$ の PFZ内において, 塑性変形 が優先的に生じたとは考えられないためである。したがっ て, 本研究で用いた鋼種の粒界破壊に対しては, 転位堆積 によるマトリクス/粒界析出物の剥離が主要な因子であ り, PFZは生成した粒界マイクロボイドの成長・拡大を促 進する軟質層として, 粒界破壊プロセスの進行を補助する 役割を担ったものと考える。また, Fig.15と Fig.17にそれ ぞれ示したEBSD解析と TEM観察の結果によると, 7Ni-PA 材および $11 \mathrm{Ni}-\mathrm{PA}$ 材ともに, 塑性変形の痕跡であるすべり 線や变形双晶が粒界へと衝突している様子が認められてお り, これらも粒界炭化物の存在と協働して, 粒界破壞の核 となるマイクロボイド形成に関与したものと考えられる。

以上のような粒界破壊プロセスは, 水素の存在に関係な く, 時効硬化した本研究の対象材にて生じる破壊様式であ る。このプロセスに及ぼす水素の影響について議論するに 先立ち, 水素未チャージ材が粒界破壊に至るまでの詳細な 過程を, Fig.18 (a)〜 (f) に示す模式図に基づいて説明する。 まず, 引張変形の初期段階で, はFCC 格子の最稠密面であ
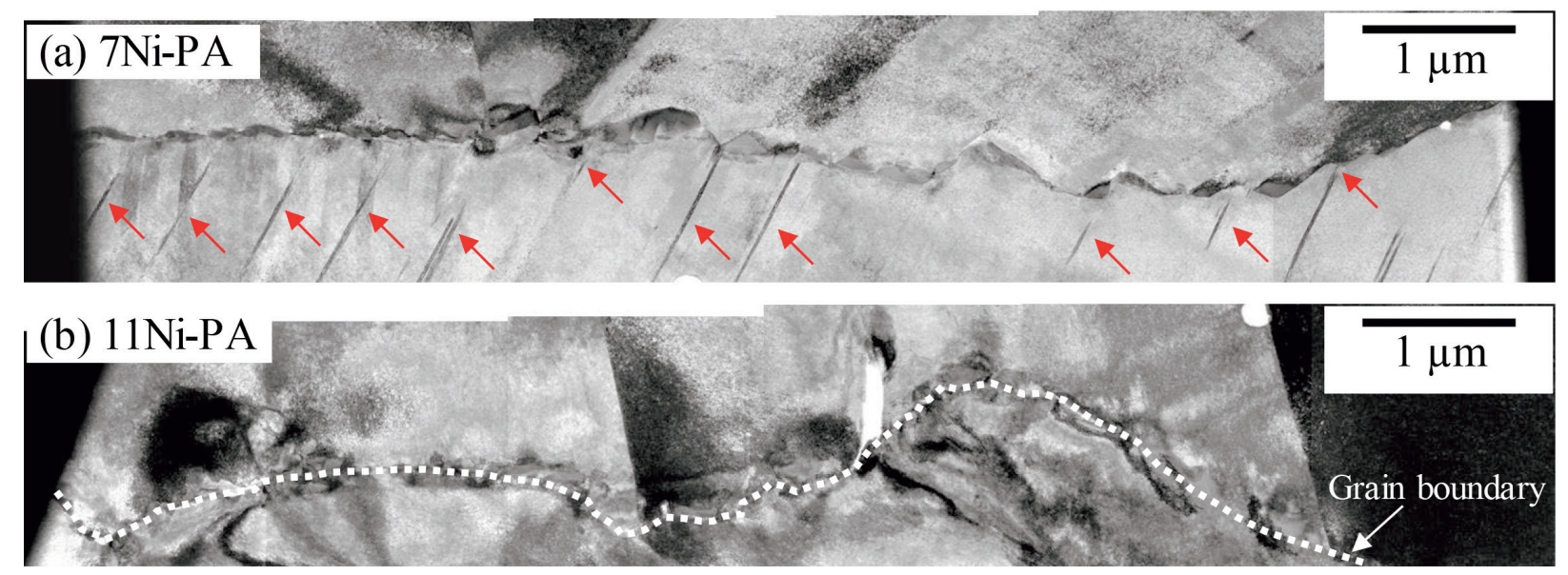

Fig. 17. TEM images around the grain boundaries in fractured hydrogen-charged $\left(100 \mathrm{MPa}, 270^{\circ} \mathrm{C}\right)$ specimens of (a) $7 \mathrm{Ni}-\mathrm{PA}$ and $(\mathrm{b})$ $11 \mathrm{Ni}-\mathrm{PA}$. Red arrows indicate deformation twins. (Online version in color.) 
る $\{111\}$ 面上にすべり変形が生じ, 粒内の転位源から発生 した転位が粒界析出物，あるいは粒界に衝突するまで移動 する (Fig.18 (a))。そして, 塑性変形の進行に伴って堆積転 位の数が増加すれば, 粒界析出物とマトリクスとの界面あ るいは粒界上に応力集中が生じる (Fig.18 (b))。転位が粒 界析出物に衝突して堆積した場合には，析出物/マトリク ス界面の剥離が生じ，マイクロボイドが発生する ${ }^{23,24)}$ 。一 方，直接粒界へと衝突した転位も，隣接結晶粒へ通り抜け ることができずに堆積し，この場合は隣接粒への転位の射 出を促す。こうした粒界に打ける転位の衝突と射出が, 粒 界内の原子配列の不規則性を高め, 粒界には原子レベルの
空孔性欠陥（フリーボリューム）が生じる。このような転 位の衝突と射出が近接する複数のすべり面上に打いて繰り 返されることで空孔性欠陥の密度が増大し，次第に成長 · 合体してマイクロボイドが形成されると推察する (Fig.18 (c)）。この一連の粒界マクロボイド形成プロセスについて は, Wan $5^{26)}$ が分子動力学シミュレーションを用い, 鉄中 の転位と粒界の相互作用を解析してその妥当性を実証して いる。さらなる塑性変形の進行により, 上記で形成された ボイドの成長・拡大が促進される (Fig.18 (d))。これに加え, 多くの $\gamma$ 鋼では変形の中期から後期になると, 転位に加え て変形双晶が塑性変形を担うようになる ${ }^{27,28)}$ 。変形双晶と

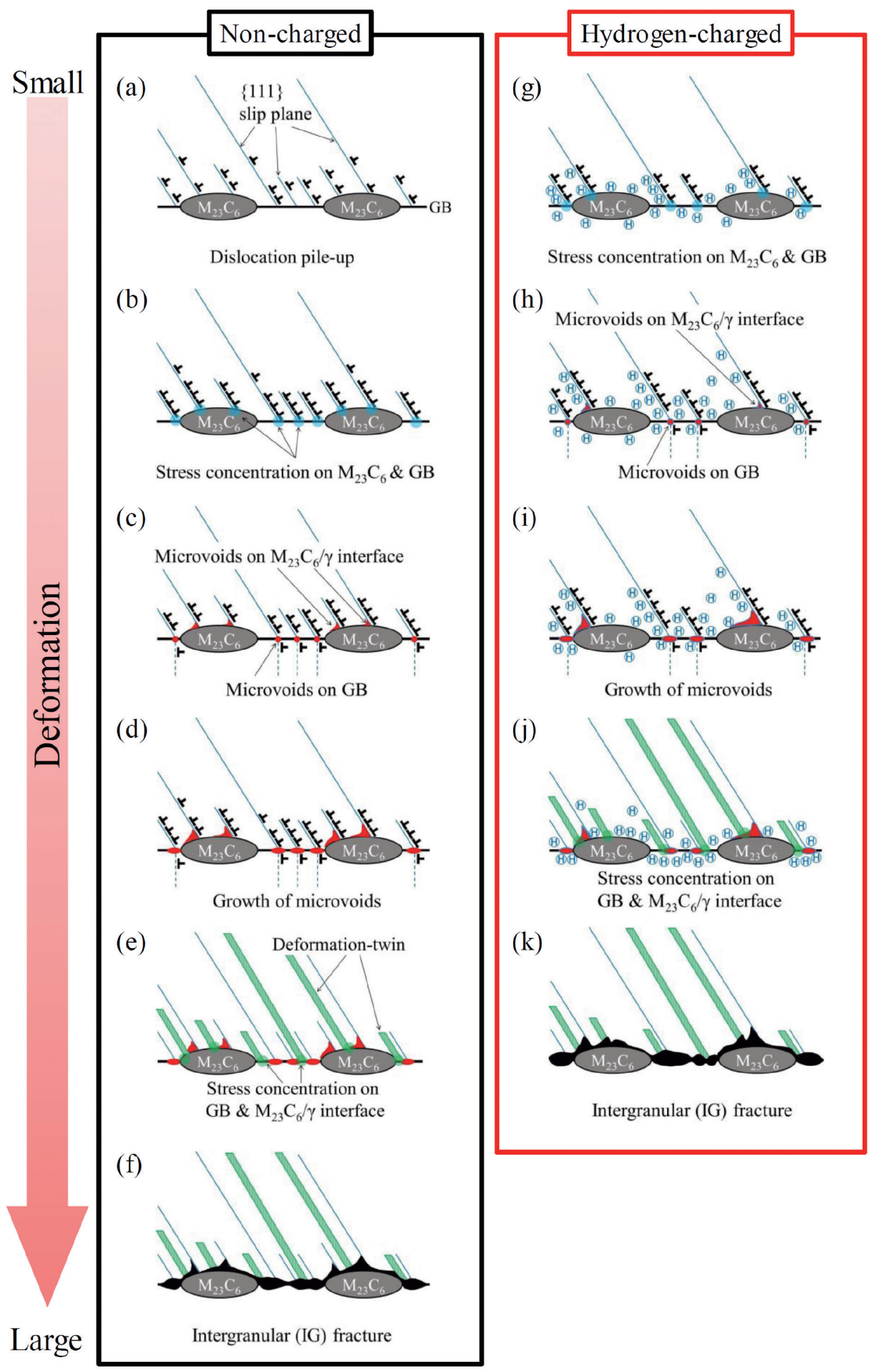

Fig. 18. Schematics of the inter-granular fracture mechanism during tensile tests of non-charged and hydrogen-charged specimens of $7 \mathrm{Ni}$ and $11 \mathrm{Ni}$ under aged condition. (Online version in color.) 
粒界との衝突部には大きな応力集中が生じ29), これが前駆 段階で形成されたマイクロボイドを連結させることで粒界 破壊に至る (Fig.18 (e)〜 (f))。以上のマイクロボイドの形 成と連結という過程を経た粒界破壞のため, 破面上にはサ ブミクロンオーダーの微小ボイドが無数に認められたもの と考えられる (Fig.13)。

\section{$4 \cdot 2$ 水素による粒界破壊促進メカニズム}

前節にて推定した水素未チャージ材の粒界破壊メカニズ ムに基づくならば, 水素による粒界破壊促進に対しても, 同様にして塑性変形が重要な因子になると考えられる。金 属材料の塑性変形に及ぼす水素の影響については多数の モデルが提案されており，その中でも代表的なものの1つ が, 水素が転位の生成と運動を助長し, 局所的な塑性変形 を促進するという水素助長局所変形 (Hydrogen-enhanced localized plasticity : HELP) 機構である ${ }^{30,31)}$ この機構は, 本研究でのSSRT試験のように遅いひずみ速度の下で, 水 素が運動する転位に追従して材料中を移動する（転位に よる水素の輸送 ${ }^{32-34)}$ ) ことで発現するとされている。さら に, 水素が塑性変形の過程で生成した空孔を安定化させ て, その凝集とクラスター化を助長し, 延性破壊の進行 を容易にするという水素助長ひずみ誘起空孔（Hydrogenenhanced strain-induced vacancies : HESIV) 機構も唱えられ ている ${ }^{34,35)}$ 。本研究の対象材と同じ析出硬化型 $\gamma$ 鋼である SUH660 あるいはA286においても，内部水素が存在する場 合に平滑破面が多く認められることが複数報告されてお り,これらの機構に立脚して，そのメカニズムが考察され ている ${ }^{11,12,36-39)}$

Imade ${ }^{11)}$ と Hicks and Altstetter ${ }^{36)}$ は, A286の引張試験で 認められた平滑破面は, 粒内のすべり面または焼なまし双 晶界面の分離によって形成されたと推定している。本研究 で用いた7Nijよび11 Ni は水素によって平滑破面の発生 が促進された点はこれらの報告と一致するものの, 主な破 壊発生サイトは粒界であることから, 微視的メカニズムの 観点で同一であったとは言えない。一方, Tajima ${ }^{12)}$ は平 滑破面の発生箇所についての詳細な特定はしていないが, Hicks らと同じく内部水素によって平滑破面の面積率が増 大することを確認し, その理由として, 水素による局所的 なすべりの助長, すなわち HELP機構の発現を挙げている。 また, Chen $ら^{37)}$ は通常成分のA286と, Al・Tit増量して $\gamma^{\prime}\left(\mathrm{Ni}_{3}(\mathrm{Al}, \mathrm{Ti})\right)$ 相の析出量を增した供試材の水素脆化挙 動を比較し, き裂の発生箇所として結晶粒界と双晶界面の 両方を挙げている。しかし，通常成分のA286の場合は粒界 破壞しか認められて打らず, $\gamma^{\prime}$ の析出量を増加させた場合 のみに, 双晶界面での破壞が生じるとしている。Takakuwa $ら^{38,39)}$ も, 内部水素によって平滑破面の形成が促進され ることを確認して打り，き裂発生サイトは主に粒界であ ると報告している。彼らは, 粒界破壊に至るまでの塑性変 形過程に対し, HELPおよびHESIV機構に立脚した水素
の振舞いを当てはめ, 独自の破壊モデルを提案している。 Takakuwa らの粒界破壞モデルには, 粒界への転位堆積, 粒 界マイクロボイド形成, 変形双晶という, 前節で挙げた 3 つの重要因子が全て含まれている。7Niおよび11NiはA286 とは材料組成が大きく異なるものの, いずれも $\gamma$ マトリク スの材料であるため, 塑性変形開始から粒界破壊に至るま での挙動は互いに類似していると考えられる。そこで本研 究では, Takakuwaらが提唱したモデルをべースに, 析出強 化型高 $\mathrm{Mn}-\gamma$ 鋼の粒界破壊プロセスに及ぼす水素の影響に ついて以下のように考察した。Fig.18 (g)〜 (k) に, その模 式図を示す。

材料中に内部水素が存在する場合, まずは特定の $\{111\}$ 面上で転位運動が活性化されて, 変形を担うすべり面の総 数が水素未チャージ材の場合よりも減少する。これによっ てすべりの局在化 (HELP機構) が起こり，すべり面当たり の粒界堆積転位の数が増加する (Fig.18 (g))。加えて, 転 位の粒界堆積に伴い, 粒内に分布していた水素は粒界の近 傍へと運搬され，偏析する。転位が粒界析出物と衝突する 場合, 堆積転位による応力集中にてマトリクスと粒界析出 物界面の剥離が生じる。この際に水素は, マトリクスと析 出物界面の結合エネルギーを低下させ，マイクロボイドの 発生を早める働きをする。このように, 水素が直接的に材 料の原子間結合力や界面の結合エネルギーを低下させて破 壊を助長するという機構は, 格子脆化 (Hydrogen-enhanced decohesion : HEDE) 機構 ${ }^{40,41)}$ と呼ばれ, 水素の存在下での 破壞促進メカニズムの一つとして知られている。一方, 直 接粒界へと転位が堆積する場合には, 粒界偏析した水素が 先述の転位衝突・射出プロセスによって形成された空孔 性欠陥を安定化させてそのクラスター化を助長し (HESIV 機構), 内部水素が存在しない状態よりもマイクロボイド の発生が早まる (Fig.18 (h) ) ${ }^{26,42)}$ 。その後は水素未チャージ の場合と同様に, 変形双晶が形成されて粒界に応力集中が 生じる ${ }^{29)}(\mathrm{Fig} .18(\mathrm{i}) \sim(\mathrm{j}))$ が, 水素は双晶変形を促進し, その開始点を低ひずみ側へ移行させることが知られてい

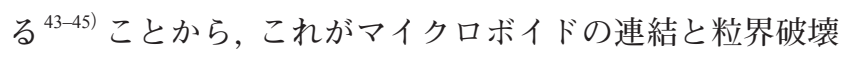
をより一層早める要因となる。以上のように, 析出強化型 高Mn- $\gamma$ 鋼において, 水素はHELP, HEDE およびHESIV 機 構全ての発現を通し, 同鋼特有の粒界破壞プロセスを促進 する因子として働き，延性低下を引き起こしたと考える。

\section{$4 \cdot 3$ 耐水素性に及ぼす $\mathrm{Ni}$ 含有量の影響}

本研究で実施した一連のSSRT試験では, Ni増量した $11 \mathrm{Ni}$ の方が $7 \mathrm{Ni} よ り も$ 耐水素性に優れていた。 $\gamma$ 鋼におい ては, SUS304のように塑性変形中に加工誘起マルテンサ イト変態を起こす場合, 水素脆化感受性が高くなること が報告されている ${ }^{46)}$ 。これは, 水素を多量に含んだ FCC 相 が水素固溶度の小さいBCC相へと瞬時に変態することに

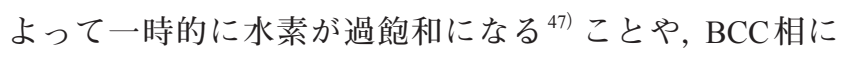
打ける水素の拡散係数が $\mathrm{FCC}$ 相よりも大きいため, 水素 
の移動・集積が容易であることが理由とされている ${ }^{5,6)}$ ○ 相の安定性は $\mathrm{Ni}$ 含有量と強い相関を持つため, $7 \mathrm{Ni}$ の方が $11 \mathrm{Ni}$ よりも加工誘起マルテンサイト変態が起こり易い。そ のため, 鋼種間で生じた耐水素性の差も, 引張変形中の加 工誘起マルテンサイト変態の有無に起因している可能性 がある。しかしながら, Fig.15で示した通り, 破断した水素 チャージ材では両鋼種とも加工誘起マルテンサイト変態は 認められなかった。一方, 他に確認された $7 \mathrm{Ni}$ と $11 \mathrm{Ni}$ の相 違点は, 引張変形後に打ける変形双晶の発生挙動である。 Fig.15 で示したEBSD解析結果では, 7Ni-PA材よりも11NiPA材において, より多くの変形双晶が発生しているように 見受けられた。しかし一方で, Fig.17で示したTEM観察結 果では, 7Ni-PA材の方が粒界近傍に多数の薄い変形双晶が 形成されていた。この矛盾点については前述の通り, 7NiPA材で発生していた変形双晶が, EBSDで判別するために は薄すぎたためであると考える。一般に, 積層欠陥エネル ギー（Stacking fault energy, SFE）が低い材料ほど, 完全転 位が2本のショックレー部分転位へと拡張する傾向が強く なり，らせん転位の交差すべりが困難となって転位運動が プラナー化し易い。また, FCC 結晶中の変形双晶は拡張転

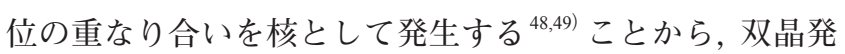
生の傾向もまた, SFEの低さに律速される ${ }^{42,50,51)}$ 。SFEは合 金組成に強く依存し, SUS304 PSUS316をべースとした 系ステンレス鋼の調査では，主にNiが SFEを上昇させる ことが報告されている ${ }^{52-54)}$ 。すおお，11Niよりも7Niに おいて SFEは低くなると考えられ，プラナーな転位運動と 変形双晶が生じ易かったものと考える。また, SFEが低く （交差すべりを起こしにくく）なるにつれ，転位堆積による バックストレス成分の増加, 動的回復の抑制, 変形双晶に よる Dynamic Hall-Petch効果等を通じて, 引張試験中の加 工硬化率が高くなる ${ }^{50,55-57)}$ 。Fig.19に, 水素未チャージ状態 の7Ni-PA材と $11 \mathrm{Ni}-\mathrm{PA}$ 材のSSRT 試験結果から導出した, 真応力 - 真ひずみ線図と加工硬化率曲線を示す。7Ni-PA材 の加工硬化率は僅かではあるが $11 \mathrm{Ni}-\mathrm{PA}$ 材よりも高く推移

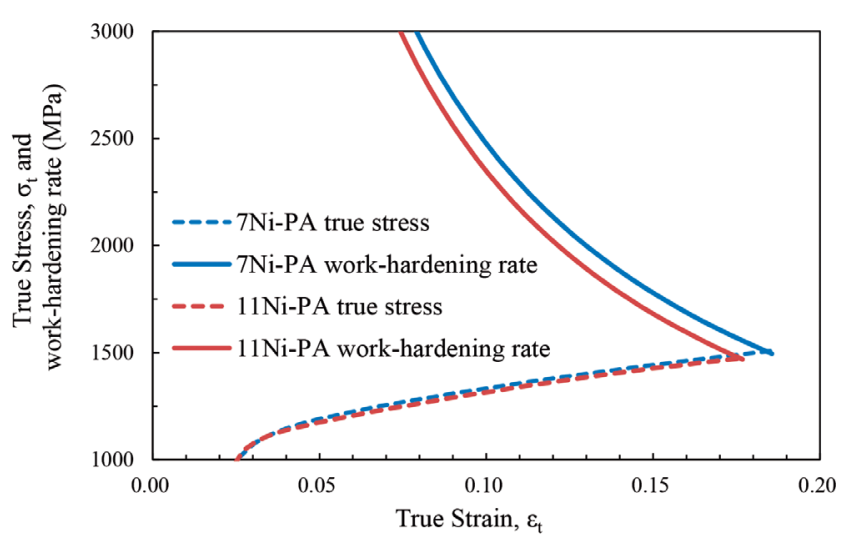

Fig. 19. True stress-true strain and work-hardening rate curves of non-charged specimens of $7 \mathrm{Ni}-\mathrm{PA}$ and $11 \mathrm{Ni}-\mathrm{PA}$. (Online version in color.)
しており，7Ni-PA材は11Ni-PA材よりも SFEが低い材料で あることを示唆している。さらに, 変形双晶の厚さはSFE が低いほど薄くなる ${ }^{58)} 。 7 \mathrm{Ni}-\mathrm{PA}$ 材中の変形双晶が EBSDで は判別できず，TEMによる高倍率観察にて初めて確認でき るほど薄かった事実も，7Ni-PA材の方が低SFEであること を支持している。

転位プラナリティの上昇は粒界へ堆積した転位の交差す ベりを抑制し, 変形双晶は前述のように粒界との衝突部に 応力集中を招く ${ }^{29)}$ 。これらの現象が生じ易い材料, すなわ ちSFEが低い材料ほど, 粒界破壊も生じ易くなる。このこ とは, 水素未チャージ材の場合に, $7 \mathrm{Ni}$ 時効材の方が $11 \mathrm{Ni}$ 時効材よりもディンプル破面率が低かったこと（Fig.12） とも整合する。水素チャージ材の場合, $7 \mathrm{Ni}$ と $11 \mathrm{Ni}$ の差は, ディンプル破面率に加えてRRAに対しても顕著に現れた (Fig.9)。7Niは11Niよりも SFEが低いため, 水素によるす ベりの局在化とプラナーな転位運動が相まって転位堆積が 進行し (Fig.18 (g)) , そこへ変形双晶による応力集中 (Fig.18 (j)) が協働して粒界破壞が促進され, 平滑破面率の増大と, それに伴う絞りの低下を招いたと考える。

\section{$4 \cdot 4$ 耐水素性に及ぼすVC析出の影響}

TEMでVC粒子の析出が確認されたPA材およびOA材 では, TDA測定において, ST材やUA材では認められな かった高温側 $\left(500 \sim 550^{\circ} \mathrm{C}\right.$ 付近) の水素放出ピークが観測 された。この高温側で放出された水素はVC粒子にトラッ プされていたものであると考える。また, ピーク温度が高 いほど, 水素脱離のための活性化エネルギーが高いと言え るため, $\mathrm{VC}$ と水素との結合エネルギーは, 格子間サイトや 結晶粒界等のものよりも大きいと考えられる。VCによる 水素卜ラップが侵入水素の粒界への集積を抑制することか ら, 高張力ボルト用鋼などにおいては, $\mathrm{VC}$ を耐水素性の改 善 (遅れ破壞の抑制) に活用している例がある ${ }^{13,14) 。 し か し ， ~}$ 本研究対象材の $11 \mathrm{Ni}$ に打いては, 強度レベルはほぼ同等で $\mathrm{VC}$ 析出状態のみが異なる UA 材と OA 材とで水素脆化の程 度（RRA）に大きな差は無く, また PA材は圧力 $0.7 \mathrm{MPa} の$ 水素チャージにて侵入させた 3 mass ppm 程度の水素量で も延性が低下した。これらの結果から, VC析出による水 素トラップは, $7 \mathrm{Ni}$ および $11 \mathrm{Ni}$ において耐水素性の改善に はほとんど寄与しなかったと結論できる。この理由として は, 侵入した水素の総量が, $\mathrm{VC}$ 粒子にてトラップできる水 素量を超えていたことが挙げられる。Fig.6に示す通り，格 子間サイトまたは結晶粒界からの水素放出を示す $400^{\circ} \mathrm{C}$ 近 傍の水素放出ピークは全ての供試材に共通して認められ た。これらの未トラップ状態の水素が, Fig.18 (g)〜 (k) で 示したようなHELP, HESIVおよびHEDE機構を介した粒 界破壊を促進した結果, $\mathrm{VC} に よ る$ 水素脆化抑制効果が表 れなかったと考える。このため, 時効条件に依存して, VC の析出形態や分散状態は変化するが, いずれの時効状態で あっても, 粒界破壊を促進させる水素の挙動は変わらず, 
Fig.18 $(\mathrm{g})$ ～(k) で示した水素の破壊促進モデルは, どの時 効条件にも共通するものと考える。

\section{$4 \cdot 5$ 耐水素性改善方法の検討}

本研究で推定された粒界破壊メカニズムと $\mathrm{Ni}$ 増量によ る耐水素性の改善効果に基づくと, 水素によって助長され るすべりの局在化，および変形双晶の発生を抑制すること が, 今回調査した $11 \mathrm{Ni}$ よりも更に耐水素性を高めた合金 を見出す鍵であると考える。その方法の一つに, SFEを上 昇させるための成分調整が挙げられる。その狙いは, 交差 すべりを促進することによって，転位堆積による粒界への 応力集中を緩和することである。ただし, SFE増減の合金 成分依存性に関して知見がほとんどない本研究の対象材 でその効果を検証するには，特に含有量の多い $\mathrm{Cr}, \mathrm{Ni}$ およ びMnの量を調整し, 各々がSFEの増減に及ぼす影響を見 極めるところから始める必要がある。一方, 最近 Koyama $ら^{59,60)}$ は20 mass \%以上のMnを含む Fe-Mn合金, および Cr-Co-Fe-Mn-Niの 5 元系ハイエントロピー合金の耐水素性 に関する研究を通して, 粒界破壊発生の抑制には, Mnの減 量が有効となる場合があることを確認し，その理由として $\mathrm{Mn}$ 自体に粒界強度の低下を招く効果があるためと考察し ている。本研究対象材の Mn 添加量は 8.5 mass \%に統一し ているが，高圧水素環境中における耐水素性の更なる向上 には，加工誘起マルテンサイト変態を回避することを前提 に咹定度を確保しつつ, SFEの上昇，そして粒界強度への 影響を考慮した Mn 添加量の最適化を図ることが重要であ ると考える。

\section{5. 結言}

Fe-10Cr-7Ni-8.5Mn および Fe-10Cr-11Ni-8.5Mn 基 VC析出 硬化型高 $\mathrm{Mn}-\gamma$ 鋼に着目し，その耐水素性に及ぼす $\mathrm{Ni}$ 含有 量ならびに時効熱処理の影響について調査するとともに, 引張試験に打ける破壊メカニズムについて検討した。以下 に結論を示す。

（1） Ni含有量を 7 mass \%から 11 mass \%へと増量すること により，より良好な耐水素性が得られた。これは，Ni 増量によって積層欠陥エネルギー（SFE）が上昇し， プラナーな転位運動および変形双晶の形成が抑制され たためと考えられる。

(2) $\mathrm{VC}$ 粒子は $\gamma$ マトリクス中においても水素トラップ効 果を示した。ただし, 約 3 mass ppmの水素が侵入した 場合でも延性は有意な低下を示し, $\gamma$ 鋼において VC粒 子の水素トラップが延性低下を抑制する効果は軽微で あった。

（3）時効熱処理は, 水素未チャージ材における引張破断時 の粒界破面率を増大させ，さらに鋼中に水素が侵入す ることで水素未チャージ材よりも一層粒界破壊率が増 大し，延性は低下した。
（4）時効熱処理により, 粒内の微細な VC析出とともに, 粒 界上への $\mathrm{M}_{23} \mathrm{C}_{6}$ 系炭化物の析出と, 粒界に沿う無析出 帯 (PFZ) が形成する。水素未チャージの時効処理材 の場合, 引張変形が付与されることで, マトリクスと 粒界析出物界面の剥離, 隣接粒への転位射出に伴う空 孔性欠陥の生成, そしてこれらを起源とするマイクロ ボイドの成長と拡大が進行した結果，粒界破壊に至っ たと考えられる。一方, 水素チャージを施した時効処 理材の場合では, 内部水素がすべりの局在化を助長す る (HELP機構) とともに, 水素が転位によって粒界へ と運搬されて集積し，マトリクスと粒界炭化物の界面 剥離と, 粒界上におけるマイクロボイドの形成も助長 (HEDE機構, HESIV 機構) した結果, 粒界破壊の進行 が促進されたものと考える。

\section{謝辞}

本研究の遂行に当たり, 水素侵入挙動および機械的性質 評価の実験作業に協力して頂いた九州大学大学院水素エネ ルギーシステム専攻 (現：日鉄ケミカル＆マテリアル株式 会社)の浅沼勇気氏に感謝いたします。

\section{文献}

1) Hydrogen and Fuel Cell Strategy Council: The Strategic Road Map for Hydrogen and Fuel Cells - Industry-academia-government action plan to realize a "Hydrogen Society" -, (March 12, 2019), https://www.meti.go.jp/english/press/2019/pdf/0312_002b.pdf, (accessed 2021-09-09).

2 ) The Association of Hydrogen Supply and Utilization Technology (HySUT): The Situation Surrounding FCV and Hydrogen Supply Station, (July 21, 2017), https://www.fdma.go.jp/singi_kento/kento/ items/kento223_03_shiryo1-2-1.pdf, (accessed 2021-09-09), (in Japanese)

3 ) M.Nagumo: Suisozeisei no Kiso (Basis of Hydrogen Embrittlement), Uchida Rokakuho Publishing, Tokyo, (2008), 197 (in Japanese).

4 ) F.Terasaki and N.Takano: Materia Jpn., 33(1994), 922 (in Japanese). https://doi.org/10.2320/materia.33.922

5 ) G.R.Caskey, Jr.: Hydrogen Degradation of Ferrous Alloys, ed. by R.A.Oriani, J.P.Hirth and M.Smialowski, Noyes Publications, Park Ridge, NJ, (1985), 855.

6 ) T.Omura, K.Kobayashi, M.Miyahara and T.Kudo: Zairyo-toKankyo, 55(2006), 537 (in Japanese). https://doi.org/10.3323/ jcorr.55.537

7 ) T.Yamamura: Zairyo-to-Kankyo, 63(2014), 483 (in Japanese). https://doi.org/10.3323/jcorr.63.483

8 ) M.Tamura and K.Shibata: J. Jpn. Inst. Met., 69(2005), 1039 (in Japanese). https://doi.org/10.2320/jinstmet.69.1039

9 ) P.M.Ordin: Safety Standard for Hydrogen and Hydrogen Systems: Guidelines for Hydrogen System Design, Materials Selection, Operations, Storage and Transportation, Office of Safety and Mission Assurance, NASA, Washington, DC, (1997).

10) S.Fukuyama: Sansouken Today, 7(2007), No.7, 6 (in Japanese).

11) M.Imade, L.Zhang, T.Iijima, S.Fukuyama and K.Yokogawa: $J$. Jpn. Inst. Met., 73(2009), 245 (in Japanese). https://doi.org/10.2320/ jinstmet.73.245

12) N.Tajima, A.Orita, T.Matsuo, Y.Yamaguchi, J.Yamabe and 
S.Matsuoka: Trans. Jpn. Soc. Mech. Eng. A, 78(2012), 1173 (in Japanese). https://doi.org/10.1299/kikaia.78.1173

13) K.Kawakami: Shinnittetsu Giho, 392(2012), 14 (in Japanese).

14) M.Kubota, T.Tarui, S.Yamasaki and T.Ochi: Shinnittetsu Giho, 381(2004), 57 (in Japanese).

15) T.Kushida, H.Matsumoto, N.Kuratomi, T.Tsumura, F.Nakasato and T.Kudo: Tetsu-to-Hagané, 82(1996), 297 (in Japanese). https://doi. org/10.2355/tetsutohagane1955.82.4_297

16) T.Hirayama and M.Ogirima: J. Jpn. Inst. Met., 34(1970), 507 (in Japanese). https://doi.org/10.2320/jinstmet1952.34.5_507

17) Y.Asanuma, H.Matsunaga, J.Yamabe, S.Matsuoka, T.Hosoda and K.Nakama: CAMP-ISIJ, 29(2016), 297, CD-ROM (in Japanese).

18) K.Takai: Zairyo-to-Kankyo, 60(2011), 230 (in Japanese). https://doi. org/10.3323/jcorr.60.230

19) K.Narita: Nippon Kagaku Zassi, 79(1958), 108 (in Japanese). https:// doi.org/10.1246/nikkashi1948.79.108

20) K.Nishino and N.Kagawa: Tetsu-to-Hagané, 58(1972), 107 (in Japanese). https://doi.org/10.2355/tetsutohagane1955.58.1_107

21) K.Osozawa: Corros. Eng. Dig., 22(1973), 267 (in Japanese). https:// doi.org/10.3323/jcorr1954.22.7_267

22) C.S.Marchi, B.P.Somerday and S.L.Robinson: Int. J. Hydrog. Energy, 32(2007), 100. https://doi.org/10.1016/j.ijhydene.2006.05. 008

23) Y.Ohmori and Y.Maehara: J. Jpn. Inst. Met., 48(1984), 158 (in Japanese). https://doi.org/10.2320/jinstmet1952.48.2_158

24) T.Ogura, S.Hirosawa, A.Cerezo and T.Sato: Acta Mater., 58(2010), 5714. https://doi.org/10.1016/j.actamat.2010.06.046

25) T.Kizuka: J. Jpn. Inst. Light Met., 63(2013), 286 (in Japanese). https://doi.org/10.2464/jilm.63.286

26) L.Wan, W.T.Geng, A.Ishii, J.-P.Du, Q.Mei, N.Ishikawa, H.Kimizuka and S.Ogata: Int. J. Plast., 112(2019), 206. https://doi.org/10.1016/ j.ijplas.2018.08.013

27) T.S.Byun, N.Hashimoto and K.Farrell: Acta Mater., 52(2004), 3889. https://doi.org/10.1016/j.actamat.2004.05.003

28) F.Hamdi and S.Asgari: Metall. Mater. Trans. A, 39(2008), 294. https://doi.org/10.1007/s11661-007-9356-6

29) L.Rémy: Metall. Trans. A, 12(1981), 387. https://doi.org/10.1007/ BF02648536

30) H.K.Birnbaum and P.Sofronis: Mater. Sci. Eng. A, 176(1994), 191. https://doi.org/10.1016/0921-5093(94)90975-X

31) P.J.Ferreira, I.M.Robertson and H.K.Birnbaum: Acta Mater., 47(1999), 2991. https://doi.org/10.1016/S1359-6454(99)00156-1 Get rights and content

32) J.Tien, A.W.Thompson, I.M.Bernstein and R.J.Richards: Metall. Trans. A, 7(1976), 821. https://doi.org/10.1007/BF02644079

33) M.Hashimoto and R.M.Latanision: Metall. Trans. A, 19(1988), 2789. https://doi.org/10.1007/BF02645813

34) M.Nagumo: Mater. Sci. Technol., 20(2004), 940. https://doi. org/10.1179/026708304225019687

35) M.Nagumo and K.Takai: Acta Mater., 165(2019), 722. https://doi. org/10.1016/j.actamat.2018.12.013

36) P.D.Hicks and C.J.Altstetter: Metall. Trans. A, 21(1990), 365. https:// doi.org/10.1007/BF02782416

37) S.Chen, M.Zhao and L.Rong: Mater. Sci. Eng. A, 561(2013), 7. https://doi.org/10.1016/j.msea.2012.10.069
38) O.Takakuwa, Y.Ogawa, J.Yamabe and H.Matsunaga: Proc. M\&M 2017 Conf., The Japan Society of Mechanical Engineers, Tokyo, (2017), OS1802 (in Japanese).

39) O.Takakuwa, Y.Ogawa, J.Yamabe and H.Matsunaga: Mater. Sci. Eng. A, 739(2019), 335. https://doi.org/10.1016/j.msea.2018.10.040

40) A.R.Troiano: Metallogr. Microstruct. Anal., 5(2016), 557. https:// doi.org/10.1007/s13632-016-0319-4

41) R.A.Oriani and P.H.Josephic: Acta Metall., 22(1974), 1065. https:// doi.org/10.1016/0001-6160(74)90061-3

42) Y.Ding, H.Yu, K.Zhao, M.Lin, S.Xiao, M.Ortiz, J.He and Z.Zhang: Scr. Mater., 204(2021), 114122. https://doi.org/10.1016/j.scriptamat. 2021.114122

43) L.Remy: Acta Metall., 25(1977), 173. https://doi.org/10.1016/00016160(77) $90120-1$

44) K.Yamada, M.Koyama, T.Kaneko and K.Tsuzaki: Scr. Mater., 105(2015), 54. https://doi.org/10.1016/j.scriptamat.2015.05.007

45) Y.Ogawa, H.Hosoi, K.Tsuzaki, T.Redarce, O.Takakuwa and H.Matsunaga: Acta Mater., 199(2020), 181. https://doi.org/10.1016/ j.actamat.2020.08.024

46) G.Han, J.He, S.Fukuyama and K.Yokogawa: Acta Mater., 46(1998), 4559. https://doi.org/10.1016/S1359-6454(98)00136-0

47) L.Zhang, Z.Li, J.Zheng, Y.Zhao, P.Xu, C.Zhou and X.Li: Int. J. Hydrog. Energy, 38(2013), 8208. https://doi.org/10.1016/j.ijhydene. 2013.01.198

48) S.Mahajan and G.Y.Chin: Acta Metall., 21(1973), 1353. https:/doi. org/10.1016/0001-6160(73)90085-0

49) J.Liu, C.Chen, Y.Xu, S.Wu, S.Wu, G.Wang, H.Wang, Y.Fang and L.Meng: Scr. Mater., 137(2017), 9. https://doi.org/10.1016/j. scriptamat.2017.05.001

50) M.Yoshitake, T.Tsuchiyama and S.Takaki: Tetsu-to-Hagané, 98(2012), 223 (in Japanese). https://doi.org/10.2355/tetsutohagane. 98.223

51) T.S.Byun: Acta Mater., 51(2003), 3063. https://doi.org/10.1016/ S1359-6454(03)00117-4

52) R.E.Schramm and R.P.Reed: Metall. Trans. A, 6(1975), 1345. https://doi.org/10.1007/BF02641927

53) F.B.Pickering: Proc. Conf. Stainless Steels '84, Institute of Metals, London, (1984), 2.

54) C.G.Rhodes and A.W.Thompson: Metall. Trans. A, 8(1977), 1901. https://doi.org/10.1007/BF02646563

55) C.K.L.Davies, V.Sagar and R.N.Stevens: Acta Metall., 21(1973), 1343. https://doi.org/10.1016/0001-6160(73)90084-9

56) A.Rohatgi, K.S.Vecchio and G.T.Gray,III: Metall. Mater. Trans. A, 32(2001), 135. https://doi.org/10.1007/s11661-001-0109-7

57) I.Gutiérrez-Urrutia and D.Raabe: Acta Mater., 60(2012), 5791. https://doi.org/10.1016/j.actamat.2012.07.018

58) Y.Zhang, N.R.Tao and K.Lu: Scr. Mater., 60(2009), 211. https://doi. org/10.1016/j.scriptamat.2008.10.005

59) M.Koyama, S.Okazaki, T.Sawaguchi and K.Tsuzaki: Metall. Mater. Trans. A, 47(2016), 2656. https://doi.org/10.1007/s11661-016-3431-9

60) M.Koyama, H.Wang, V.K.Verma, K.Tsuzaki and E.Akiyama: Metall. Mater. Trans. A, 51(2020), 5612. https://doi.org/10.1007/ s11661-020-05966-z 